\title{
Potential Applications of Geopolymer Cement-Based Composite as Self-Cleaning Coating: A Review
}

\author{
Siti Norsaffirah Zailan ${ }^{1}$, Norsuria Mahmed 1,2,*, Mohd Mustafa Al Bakri Abdullah 1,2,*, \\ Shayfull Zamree Abd Rahim ${ }^{1,3}$, Dewi Suriyani Che Halin ${ }^{1,2} \mathbb{D}$, Andrei Victor Sandu ${ }^{4,5, * \mathbb{D}}$, \\ Petrica Vizureanu ${ }^{4,6}$ (D) and Zarina Yahya ${ }^{1}$
}

Citation: Zailan, S.N.; Mahmed, N.; Abdullah, M.M.A.B.; Rahim, S.Z.A.;

Halin, D.S.C.; Sandu, A.V.; Vizureanu, P.; Yahya, Z. Potential Applications of Geopolymer Cement-Based Composite as Self-Cleaning Coating: A Review. Coatings 2022, 12, 133.

https: / / doi.org/10.3390/

coatings12020133

Academic Editors: Tomasz Mościcki and Justyna Chrzanowska-

Giżyńska

Received: 23 December 2021

Accepted: 19 January 2022

Published: 24 January 2022

Publisher's Note: MDPI stays neutral with regard to jurisdictional claims in published maps and institutional affiliations.

Copyright: (C) 2022 by the authors. Licensee MDPI, Basel, Switzerland. This article is an open access article distributed under the terms and conditions of the Creative Commons Attribution (CC BY) license (https:// creativecommons.org/licenses/by/ $4.0 /)$
1 Centre of Excellence Geopolymer and Green Technology (CEGeoGTech), Universiti Malaysia Perlis (UniMAP), Perlis 01000, Malaysia; sitinorsaffirah@yahoo.com (S.N.Z.); shayfull@unimap.edu.my (S.Z.A.R.); dewisuriyani@unimap.edu.my (D.S.C.H.); zarinayahya@unimap.edu.my (Z.Y.)

2 Faculty of Chemical Engineering Technology, Universiti Malaysia Perlis (UniMAP), Perlis 01000, Malaysia

3 Faculty of Mechanical Engineering Technology, Universiti Malaysia Perlis (UniMAP), Perlis 02600, Malaysia

4 Faculty of Materials Science and Engineering, Gheorghe Asachi Technical University of Iaşi, Blvd Mangeron, No. 51, 700050 Iasi, Romania; peviz@tuiasi.ro

5 Romanian Inventors Forum, St. P. Movila 3, 700089 Iasi, Romania

6 Technical Sciences Academy of Romania, Dacia Blvd 26, 030167 Bucharest, Romania

* Correspondence: norsuria@unimap.edu.my (N.M.); mustafa_albakri@unimap.edu.my (M.M.A.B.A.); sav@tuiasi.ro (A.V.S.)

\begin{abstract}
Nowadays, concepts of self-cleaning have received great attention in construction building materials. Self-cleaning with the presence of photocatalyst has been applied in building materials to overcome the problem of building surfaces becoming dirty after exposure for a long time in highly polluted areas. To date, the concept of green blending materials has led to the development of a new binding material for green materials, which is geopolymer with an addition of photocatalyst. This review focused on the development of conventional self-cleaning paste, including the method of preparation and the impact of adding photocatalyst on physical and mechanical properties. However, although self-cleaning has been widely applied in conventional cement paste, its applications in geopolymers are still in the early stages of development and require more research. Therefore, this paper also intended to review the current knowledge on properties of geopolymer cement-based composite and its potential to be applied as a self-cleaning coating.
\end{abstract}

Keywords: self-cleaning; geopolymer; nanoparticles; photocatalyst; coating

\section{Introduction}

Concrete is most widely used as a material in the construction industries [1]. Among others, Portland cement is the most common type of concrete utilized as construction material [2]. The demand of this type of concrete increases exponentially with city developments. Besides being used as concrete, cement is also used as a paste for surface finishing for buildings. However, the high utilization of cement or concrete causes air pollution, resulting in the negative impacts on the environment [3]. In the Ordinary Portland Cement (OPC) production processes, high amounts of carbon dioxide $\left(\mathrm{CO}_{2}\right)$ are released into the atmosphere, causing global warming [4]. Due to the high emission of greenhouse gases during manufacturing of OPC, geopolymer is an alternative material to replace the cements-based binder with industrial by-product, e.g., fly ash. In order to be developed for OPC substitution, geopolymer is an innovative, green alternative for construction material. Geopolymer was invented by Davidovits [1] and belongs to the family of inorganic polymers.

Geopolymer is the combination of the pozzolanic compound, which is also known as aluminosilicate source materials with an alkaline activator solution [5]. It was applied as paste, mortar, and concrete for construction materials. In addition, it is also commonly used in our surroundings, i.e., exterior tiles, paving blocks, etc [6]. 
Due to its physical and morphological properties, fly ash (FA), which is an industrial (coal power plant) by-product, is the most commonly used material in the production of geopolymers [7]. Fly ash is also cheap and available worldwide [8-10]. Thus, it becomes a potential source for greener cement production [10]. Instead of using Portland cement, fly ash-based geopolymer paste is becoming a viable alternative because it has the potential to reduce Portland cement usage while maintaining the physical and mechanical properties of Portland cement concrete [2]. Geopolymer was also reported to exhibit better compressive strength than OPC concrete [9].

Nowadays, most of the buildings in Malaysia have low sustainability in terms of appearance. To be more precise, the concrete of the buildings, particularly the external building walls, is suffering from a serious problem of tending to become dirty, especially in areas that have been exposed for a long time in highly polluted surroundings. Besides, natural disasters and old buildings demolition also contribute to the release of concrete dust, which results in dusty and dull appearances of building surfaces over the years.

In order to maintain the appearance of the building, the construction industry has been focusing on producing cementitious materials that not only have good physical and mechanical performance but also have an additional property to clean the surface of buildings alone. The self-cleaning concept has been applied in conventional cement and has proven better performance in terms of physical, mechanical, and self-cleaning properties. Meanwhile, in certain cases, the strength was decreased with the increase in nanoparticles photocatalyst [11].

On the other hand, few years ago, the application of nanoparticles in cement-based materials gained attention due to the unique properties of nanomaterials owing to the high reactivity, fine particle size. and specific functional properties. With the implementation of nanotechnology in construction and building materials, the performance of concrete-based material was improved and enhanced in terms of increased strength and also new materials development for other functional properties (i.e., self-cleaning properties, discoloration resistance, etc.) [12-14].

The nanoparticles of the photocatalyst, which are zinc oxide $(\mathrm{ZnO})$ and titanium oxide $\left(\mathrm{TiO}_{2}\right)$, were added in the cementitious material to develop self-cleaning properties. Photocatalyst will decompose organic and inorganic pollutants to the lesser toxic form under exposure to sunlight and ultraviolet (UV) light. The combination of photocatalyst with cementitious materials has significant advantages. For example, it has the ability to decompose unwanted organic compounds on the surface of concrete buildings, which can be easily removed by rain [15-17]. As a consequence, buildings' aesthetic appearance is maintained by keeping the surface of the buildings free from dirt and preserving the colour, even in industrial areas and polluted conditions [18].

This review focuses on previous research work on self-cleaning coating using conventional cement and has potential to be applied in geopolymer cement-based composite. Besides, this paper also reviews on using geopolymer as an alternative to OPC. Geopolymer paste has the potential to be used as finishing materials with better physical and mechanical properties in the construction industry. By adding nanoparticles materials as photocatalyst for self-cleaning applications, the geopolymer properties were expanded. From the extensive reviews, the current knowledge gaps have been determined for further research. It was found that nanoparticle photocatalysts have been widely used for self-cleaning applications in conventional cement. However, their applications in geopolymer materials are still in early stages of development and require more research. On the other hand, there is a research gap in which only a few researchers are focused on physical and mechanical properties rather than self-cleaning applications and photocatalytic degradation. The benefits of introducing photocatalyst onto cementitious materials and the mechanism of photocatalytic reaction in the self-cleaning process are discussed in the following section. 


\section{Self-Cleaning}

\subsection{Self-Cleaning Mechanism}

Self-cleaning is an automatic process of cleaning. The botanist, Wilhelm Barthlott discovered the principle of self-cleaning in 1973 [16]. This is due to the photocatalytic action, which removes the pollutants when the photocatalyst has been added [19]. The properties of self-cleaning include that it is a "bio-inspired" material, mimicking biological systems that exhibit the "lotus effect." The surface exhibiting the lotus effect was created due to functionalized nanoparticles, such as $\mathrm{TiO}_{2}, \mathrm{ZnO}$, silicon oxide $\left(\mathrm{SiO}_{2}\right)$, calcium carbonate $\left(\mathrm{CaCO}_{3}\right)$, or hydroxyapatite (HA) [20].

Self-cleaning refers to the ability of a mechanism to clean surfaces by itself. Selfcleaning is used widely in cementitious materials. This is because of improved mechanical properties and performance owing to the self-cleaning properties [21]. Photocatalytic reaction consumes the energy from ultraviolet (UV) rays in order to oxidize organic compounds and to degrade the other pollutants to a lesser toxic form under exposure to sunlight. With the presence of UV radiation from the sun, photocatalytic reaction occurs. When heat and light strike the concrete surface, which are covered by a layer of photocatalytic materials, photocatalyst uses the energy to disintegrate the organic pollutant into the oxygen, water, nitrate, sulphate molecule, $\mathrm{CO}_{2}$, etc., as shown in Figure 1 [19,22-24].

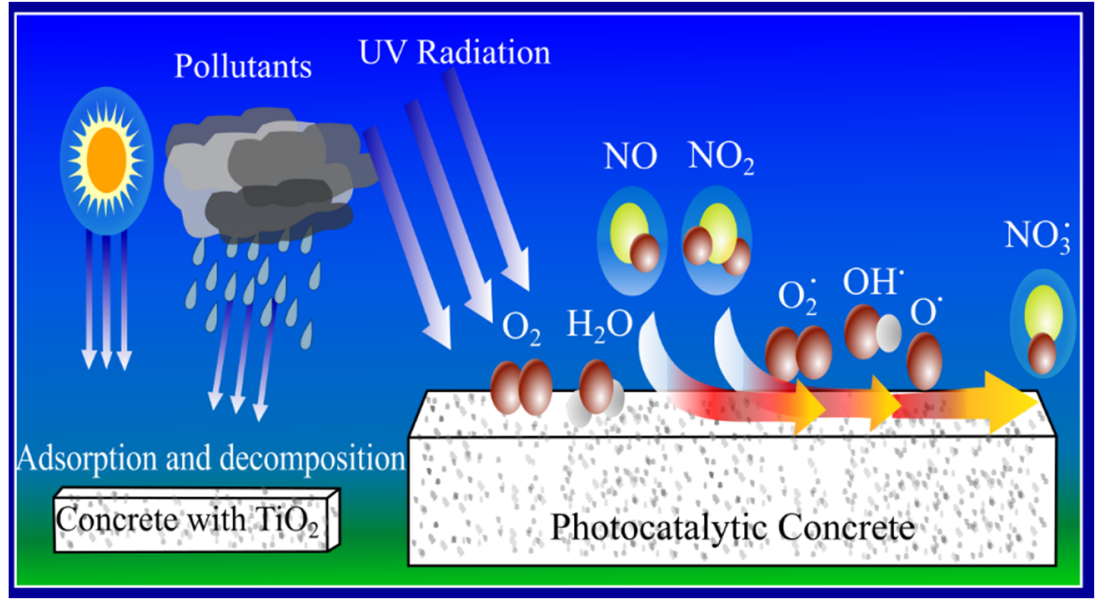

Figure 1. Mechanism of self-cleaning on surface of cementitious materials [22].

Due to the superhydrophilic surface of the photocatalyst, the reaction products from the self-cleaning process are easily removed by simple rinsing or rain [16]. The photocatalytic components consume the energy from sunlight to oxidize organic and inorganic compounds. The air pollutants, which cause discoloration to the exposed surfaces, are removed, and their residues are washed away by rain. Thus, this innovation minimizes the costs of maintenance while ensuring cleaner environment [25].

Other than that, a photocatalyst converts organic particles and air pollutants that consist of toxic to lesser toxic forms in the presence of UV radiation from the sun, e.g., nitrogen oxides ( $\mathrm{NOx}, \mathrm{NO}+\mathrm{NO}_{2}$ ) decomposed into lesser toxic forms, such as nitrogen dioxide $\left(\mathrm{NO}_{2}\right)$, nitrate $\left(\mathrm{NO}_{3}\right)$, etc. In a photocatalytic reaction, $\mathrm{NOx}$ gases are first broken down into nitric acid $\left(\mathrm{HNO}_{3}\right)$ and attached to the droplet of water. The water droplet is then washed away by rain, and nitric oxide (NO) is oxidised and converted to nitrates ions $\left(\mathrm{NO}_{3}{ }^{-}\right.$), which are then flushed away as a weak $\mathrm{HNO}_{3}$ from the surface, as shown in Figure 2. This is a promising approach for self-cleaning surfaces, and NOx degradation has successfully solved the major environmental problem of air pollution [26]. This photocatalytic reaction also contributes to volatile organic compounds (VOCs) decomposition, consequently removing the contaminants and impurities from the surrounding environment [19]. 

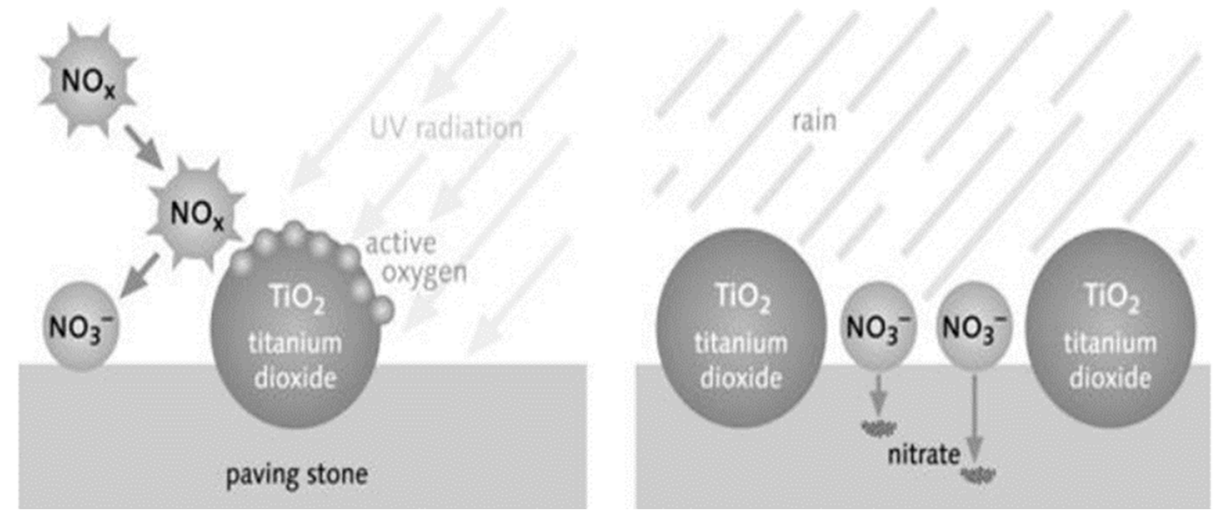

Figure 2. Photocatalytic reaction process of cementitious materials [26].

Buildings can maintain their aesthetic appearance by removing the dirt and stains on the building surface, and the air quality can be improved through the degradation of airborne pollutants $[27,28]$. Thus, the application of photocatalyst has been highlighted to achieve eco-friendly and sustainable concrete, which greatly helped lower the ecological cost in production of construction materials [29]. The application and utilization of selfcleaning in cementitious materials are discussed in the following section.

\subsection{Self-Cleaning Technology}

Self-cleaning technology is commercialized to be applied in indoor and outdoor applications. In the last few decades, indoor and outdoor pollutions are becoming significant concerns due to the exponential growth in the industrialization and urbanization over the world [30]. Nowadays, abundant technologies have evolved from nature, one of which is self-cleaning technology. There are numerous practical applications of self-cleaning technology, for example, car mirror, solar panels, window glasses, textiles, tiles, ceramics, paints, cementitious materials, etc. Self-cleaning materials have attained substantial attention due to their unique properties and have the potential to reduce maintenance costs of cleaning the surface of civil infrastructure. Self-cleaning technology has been used in a variety of products, but the most popular application is for cementitious materials that have self-cleaning properties [31-34].

According to the researchers and environmentalists, development of cement-based photocatalytic materials has widely been applied in the construction industry and extensively studied in order to produce photocatalytic finishing materials for buildings with self-cleaning properties, which simultaneously reduce the pollutants, contributing towards environmental benefits [30,35]. These applications range from architectural concrete panels and precast (e.g., sidewalks, road surfacing panels, traffic dividers, and pavements) to Portland cement-based plaster for finishing coating applications (e.g., cement paste, road coating, concrete masonry block, facade, roof tiles, and sound barriers elements) [21,25,29].

Another area qualified for receiving attention is the $\mathrm{TiO}_{2}$-based cementitious materials with self-cleaning ability. The applications of these technologies have been practically applied under visible light irradiation, which is widely utilized in indoor walls, air purifiers, and tunnels, etc., for long-term effects of air purifying and durability under real weather conditions [36]. Instead of playing the role of a photocatalyst, $\mathrm{TiO}_{2}$ has also been utilized as concrete additive and as paint for coating applications [26]. This was demonstrated in Rome in 1998, when the self-cleaning properties of modified cement-blended concrete were used for the first time in the construction of the church "Dives in Misericordia" [37].

Another application is at Dubai Sports City's Cricket Stadium, where the roof was coated with white cement containing $\mathrm{TiO}_{2}$ nanoparticles [28]. Other than that, photocatalytic cement concrete has been applied in lighting systems and the renovation of a heavy traffic tunnel in Rome [25]. Additionally, the self-cleaning of $\mathrm{TiO}_{2}$-based materials in combination with cement and paint has also been explored [30]. $\mathrm{TiO}_{2}$-based white 
cement as a cementitious binder was developed for enhancing the aesthetic durability of cementitious materials [38]. The photocatalytic building materials have the ability to mitigate air pollutants at urban areas by reducing nitrogen oxides (NOx) concentration levels to the less toxic form and maintaining their aesthetic appearance as a function of time. The photocatalyst of $\mathrm{TiO}_{2}$ was also used in concrete pavements production by mixing the nanoparticles on the pavement surface [21]. Self-cleaning using conventional cement as a coating base will be discussed in the next section.

\subsection{Conventional Self-Cleaning}

The self-cleaning paste is a promising new invention in cementitious materials and has a potential for new approach to maintain cleaner city by reducing the air pollutants in the urban areas. The photocatalytic reaction is capable of accelerating the natural oxidation process and speeding up pollutant decomposition $[19,23,24]$. The self-cleaning property of building materials displays multiple photocatalytic functions by preserving the aesthetic appearance of the building even in harsh urban environments, which reduces the costs of routine maintenance effectively and depollution that contributes to mitigating heat and urban microclimates in ensuring a cleaner environment [23,31,38-40]. In another aspect, the photocatalytic action also contributed to antimicrobial, air purifying, and self-cleaning properties in construction materials [39].

Table 1 shows a summary of research on self-cleaning coating using conventional cement. In recent research, the mechanical performances were improved by adding photocatalytic materials to the cement mortar [23]. Meanwhile, in some cases, the addition of $\mathrm{ZnO}$ nanoparticles has negative impacts on compressive strength resulting in lower strength because the water prevented the formation of cement paste in the concrete [11]. The nanoparticles photocatalyst filled in the voids between cement particles, resulting in smaller pores and improved strength, properties modification, and cementitious materials thermal, durability, mechanical, and electrical properties [41]. The effects of nano- $\mathrm{ZnO}$ on the strength, setting time, hydration, and microstructure of the cement paste were investigated by previous researcher [42]. The result demonstrates that $0.2 \mathrm{wt} . \%$ of nano- $\mathrm{ZnO}$ addition into cement paste had influenced the process of early hydration, and the hardening period was significantly prolonged. Furthermore, in terms of mechanical properties, the results demonstrated that increasing nano- $\mathrm{ZnO}$ concentrations improved the long-age strengths of cement paste. Implementation of nano- $\mathrm{ZnO}$ onto cement paste causes the pore diameter distribution to become refined, and the microstructure of the cement paste formed at 28 days is compacted.

Table 1. Research on conventional self-cleaning coating.

\begin{tabular}{|c|c|c|c|c|}
\hline No. & Author & Dosage of Nanoparticles (wt $\%$ ) & Type of Photocatalyst & Findings \\
\hline 1. & Kumar et al. [23] & $0.1,0.2$, and 2.0 & Titania-doped silver & $\begin{array}{l}\text { Mechanical properties improved } \\
\text { Strength increased }\end{array}$ \\
\hline 2. & Behfarnia et al. [11] & $\begin{array}{l}\text { Zinc oxide } \\
(0,0.5,1.0,2.0,3.0,4.0 \text {, and } 5.0) \\
\text { Titanium oxide } \\
(0,1.0,2.0,3.0,4.0 \text {, and } 5.0)\end{array}$ & $\begin{array}{l}\text { Zinc oxide } \\
\text { Titanium oxide }\end{array}$ & Strength decreased \\
\hline 3. & Rao et al. [41] & $\begin{array}{l}\text { Silicon oxide } \\
(0.75,1.50 \text {, and } 3.00) \\
\text { Titanium oxide } \\
(0.5,0.75 \text {, and } 1.00)\end{array}$ & $\begin{array}{l}\text { Silicon Oxide } \\
\text { Titanium Oxide }\end{array}$ & $\begin{array}{l}\text { Strength increased } \\
\text { Modified properties } \\
\text { Improved durability, thermal, mechanical, and electrical properties }\end{array}$ \\
\hline 4. & Liu et al. [42] & $\begin{array}{l}\text { प Titanium oxide } \\
(0.5,1.0,2.0 \text {, and } 3.0) \\
\text { Zinc oxide } \\
(0.5,1.0,1.5 \text {, and } 2.0) \\
\text { Silicon oxide } \\
(0.5,1.0,1.5,2.0 \text {, and } 3.0) \\
\text { Aluminum oxide } \\
(0.25,0.5,0.75 \text {, and } 1.0)\end{array}$ & $\begin{array}{l}\text { Titanium oxide } \\
\text { Zinc oxide } \\
\text { Silicon oxide } \\
\text { Aluminum oxide }\end{array}$ & $\begin{array}{l}\text { Setting time prolonged hardening period } \\
\text { Long-term strength with increase dosage of nano- } \mathrm{ZnO} \\
\text { Pore diameter distribution was refined } \\
\text { Microstructure of cement-paste was compact }\end{array}$ \\
\hline 5. & Hanus and Harris [31] & $\mathrm{N} / \mathrm{A}$ & $\begin{array}{l}\text { Carbon nanotubes } \\
\text { Carbon nanofibers }\end{array}$ & Produced cementitious materials with self-cleaning abilities \\
\hline
\end{tabular}


Table 1. Cont.

\begin{tabular}{|c|c|c|c|c|}
\hline No. & Author & Dosage of Nanoparticles (wt \%) & Type of Photocatalyst & Findings \\
\hline 6. & Duan et al. [43] & $1.0,3.0$, and 5.0 & Titanium oxide & $\begin{array}{l}\text { Accelerated hydration rate } \\
\text { Promoted hydration degree } \\
\text { Enhanced compressive strength } \\
\text { Enhanced flexural strength at early age } \\
\text { Incorporated } 5 \mathrm{wt} \% \text { of nano- } \mathrm{TiO}_{2} \text { enhance physio-mechanical } \\
\text { Pore structure refinement increased } \\
\text { Decreased total porosity } \\
\text { High resistance in chloride penetration }\end{array}$ \\
\hline 7. & Shen et al. [44] & $0,2.5,5.0$, and 7.5 & Titanium oxide & $\begin{array}{l}\text { Degradation of methylene blue (MB) increase as a function of time } \\
\text { as } \mathrm{TiO}_{2} \text { concentration increased }\end{array}$ \\
\hline 8. & Cohen et al. [12] & $\begin{array}{l}\text { Titanium oxide } \\
\text { (1.0 and } 3.0) \\
\text { Titanium oxynitride } \\
(0.5,1.0 \text {, and } 3.0)\end{array}$ & $\begin{array}{l}\text { Titanium oxide } \\
\text { Titanium oxynitride }\end{array}$ & Highest photoactivity by the highest photocatalyst addition \\
\hline 9. & Khatae et al. [45] & $0.5,1.0,1.5,2.0,2.5$, and 3.0 & Titanium oxide & $\begin{array}{l}\text { Partial addition of nano- } \mathrm{TiO}_{2} \text { up to } 1 \% \text { into modified white } \\
\text { Portland cement increased the compressive } \\
\text { Flexural strength increased } \\
\text { Decreased the setting time } \\
\text { Decolorizing the dye increased as the amount of nano- } \mathrm{TiO}_{2} \\
\text { increased }\end{array}$ \\
\hline 10. & Melo andTriches [46] & $3.0,6.0$, and 10.0 & Titanium oxide & $\begin{array}{l}\text { Addition of nanoparticles into cement matrix led to behaviour } \\
\text { alterations either in fresh and hardened states } \\
\text { Influenced the mechanical performance }\end{array}$ \\
\hline
\end{tabular}

The nano- $\mathrm{TiO}_{2}$ addition to the paste, mortars, or concretes as a photocatalyst produced cementitious materials with self-cleaning abilities [47]. There are tests that involve organic substances, such as the colour of dyes degradation, to verify self-cleaning performances of photocatalytic cements [38]. The photocatalytic properties of the materials were examined by degradation of methylene blue under exposure to sunlight, which increases with the function of time as the $\mathrm{TiO}_{2}$ contents ( $0 \mathrm{wt} . \%, 2.5 \mathrm{wt} . \%, 5.0 \mathrm{wt} . \%$, and $7.5 \mathrm{wt} . \%$ ) increase. It shows that the properties of the self-cleaning were enhanced by increasing the admixture [44]. The highest photoactivity of Portland cement pastes blended with different percentage of nanoparticles titanium oxynitride $(0 \%, 0.5 \%, 1.0 \%$, and $3.0 \%)$ and titanium dioxide $(1 \%$ and $3 \%)$ was determined by the sample that consists of the highest percentage of photocatalyst addition [12].

On the other hand, Duan et al. [43] published their work on a nano- $\mathrm{TiO}_{2}$ addition to the Portland cement, which accelerated the hydration rate, promoted hydration degree, and enhanced compressive strength and flexural strengths at early age. The cited authors also reported that the properties of physio-mechanical are more desirable than others when incorporating $5 \mathrm{wt} . \%$ of nano- $\mathrm{TiO}_{2}$ into cement blends. The addition of nano- $\mathrm{TiO}_{2}$ increases the pore structure refinement, decreases total porosity of cement paste, and increases resistance to chloride penetration more than in the sample containing the same amount of nano- $\mathrm{SiO}_{2}$.

In the present work, self-cleaning cement was produced by using titanium dioxide as photocatalyst and white cement, whereas in a further work, Ag was doped into $\mathrm{TiO}_{2}$ to enhance the performance of self-cleaning. The activity of photocatalytic was evaluated under sunlight and artificial light (UV light), and the results demonstrated that the prepared sample with self-cleaning ability was able to clean their surfaces [23]. The same work was presented by another author where partial addition of nano- $\mathrm{TiO}_{2}$ up to $1 \%$ into modified white Portland cement increased the compressive and flexural strength and decreased the setting time. The results indicated that as the amount of nano- $\mathrm{TiO}_{2}$ increases, the self-cleaning properties also increased by efficiently decolorizing the dye. Thus, it can be concluded that the $\mathrm{TiO}_{2}$-modified cements are suited to be used in buildings and environmental technologies [45]. However, in certain cases, loading of nanoparticles into matrix of cement led to the alteration behaviour either in fresh and hardened states and also influenced the performance in terms of mechanical properties [46]. The next section discusses the method that was discovered by previous researchers on how to prepare self-cleaning cement paste. 


\subsection{Method of Self-Cleaning Cement Preparation}

There are a lot of methods and techniques for introducing photocatalyst into building materials besides directly mixing photocatalyst with cementitious materials, for example, sol-gel dip coating method, precipitation method, ball milling, hydrothermal method, microwave assisted synthesis, pulse combustion-spray pyrolysis method, sputtering, electrophoretic deposition, thermal oxidation, chemical vapor deposition, and wet coating [33,47]. However, this traditional method has significant drawbacks, particularly coating techniques, which typically have weak adhesion substrates, resulting in low durability in harsh outdoor environments [21,48]. Consequently, the end products of cement-based photocatalytic materials included losing the ability to decompose, leading to hydration of cement product [49].

All the mixing methods of preparation of self-cleaning paste are summarized in Table 2. For homogeneous mixing of zinc oxide, the nano- $\mathrm{ZnO}$ was firstly ultra-sonicated with water for $15 \mathrm{~min}$ in a basin at ambient temperature and then added to the mixture [33]. The same method was applied by Liu et al. [42], where the nano- $\mathrm{ZnO}$ were dispersed uniformly into cement paste by using ultrasonic treatment. A previous researcher proposed nano powder of $\mathrm{ZnO}$ to be mixed with water for $30 \mathrm{~s}$ with superplasticizer first before adding the cement into the mixture [50]. The same method was used by Arefi and Zarchi [51] but by mixing $\mathrm{ZnO}$ nanoparticles in dry condition in a drum mixer for two minutes before adding water for another three minutes.

Table 2. Summary of mixing method in the preparation of self-cleaning paste.

\begin{tabular}{|c|c|c|c|}
\hline Author & Method of Mixing & Time & Dosage of Nanoparticles \\
\hline Nochaiya et al. [33] & Ultra-sonicated with water & $15 \mathrm{~min}$ & $0.0,1.0,2.0$, and 5.0 of $\mathrm{ZnO}$ nanoparticles \\
\hline Liu et al. [42] & Ultra-sonicated with water & $15 \mathrm{~min}$ & $0.0,0.05,0.1$, and 0.2 of $\mathrm{ZnO}$ nanoparticles \\
\hline Yousefi et al. [52] & Ultra-sonicated with water & 5 to $15 \mathrm{~min}$ & $0.0,0.1,0.3$, and 0.5 of $\mathrm{ZnO}$ nanoparticles \\
\hline Ma et al. [53] & Ultra-sonicated with water & $30 \mathrm{~min}$ & $0.0,1.0,2.0$, and 3.0 of $\mathrm{TiO}_{2}$ nanoparticles \\
\hline Feng et al. $[54,55]$ & $\mathrm{TiO}_{2}$ and cement soaked in water and ultrasonically vibrated & $30 \mathrm{~min}$ & $0.0,0.5,1.0$, and 1.5 of $\mathrm{TiO}_{2}$ nanoparticles \\
\hline Nivethitha et al. [50] & Mixed with water and superplasticizer & $30 \mathrm{~s}$ & $0.0,1.0,3.0$, and 5.0 of $\mathrm{ZnO}$ nanoparticles \\
\hline Arefi et al. [56] & ZnO dry-mixed in drum mixer & $2 \mathrm{~min}$ & $0.0,0.05,0.1,0.2,0.5$, and 1.0 of $\mathrm{ZnO}$ nanoparticles \\
\hline Aissa et al. [57] & Dry-mixed $\mathrm{TiO}_{2}$ and cement & $30 \mathrm{~s}$ & $0.0,1.0,2.5,5.0$, and 10.0 of $\mathrm{TiO}_{2}$ nanoparticles \\
\hline Duan et al. [43] & Dry-mixed $\mathrm{TiO}_{2}$ with fly ash & - & $0.0,1.0,3.0$, and 5.0 of $\mathrm{TiO}_{2}$ nanoparticles \\
\hline Shen et al. [44] & Mixed using ball mill with diameter $500 \mathrm{~mm}$ & $30 \mathrm{~min}$ & $0.0,2.5,5.0$, and 7.5 of $\mathrm{TiO}_{2}$ nanoparticles \\
\hline
\end{tabular}

In order to achieve even distribution before the mixing process, a similar method of mixing was applied by other researchers, but the $\mathrm{TiO}_{2}$ nanoparticles and cement were soaked in water and vibrated ultrasonically for $30 \mathrm{~min}$ [54]. On the other hand, Duan et al. [58] reported the purpose of vibration is to remove the entrained air. Other researchers reported that the $\mathrm{TiO}_{2}$ powder was added to dry cement, and subsequently water was added before the mixing process $[44,56]$. In another approach, prior cement mortars were cast at a sand-binder replacement with fly ash $(0 \%, 10 \%, 20 \%$, and $30 \%$ by cement-mass), and nano- $-\mathrm{TiO}_{2}$ with dosage $0 \%$ to $3 \%$ was added to deionized water, stirred, and dispersed by ultrasonication at $325 \mathrm{~W}$ for $30 \mathrm{~min}$ for the uniform suspensions [53]. In order to avoid nano- $\mathrm{TiO}_{2}$ in cement mixes agglomerate, effective dispersion of the in lime-saturated water and deionized water followed by mechanical treatment of ultrasonication to enhance the photocatalytic properties in cement mixes are crucial [52].

In the preparation stage, coating on existing buildings or mixing with binding materials was applied in cementitious materials with titanium oxide as photocatalyst [39]. Guo et al. [49] reported on the intermixing method, where paint coating-based $\mathrm{TiO}_{2}$ and $\mathrm{P} 25$ suspension coating were applied to incorporate $\mathrm{TiO}_{2}$ into self-compacting architectural mortars. Photocatalytic cementitious materials have been utilized practically by either directly spraying on the surface of cementitious materials of $\mathrm{TiO}_{2}$ photocatalysts or intermixing the photocatalysts into the raw materials [49]. Yang et al. [58] worked with 
industrial waste, where zeolite fly ash bead generated from coal power plant acted as a carrier of $\mathrm{TiO}_{2}$ photocatalyst, which was applied by intermixing method, and the surface of photocatalytic cementitious materials was sprayed for long-term performance in cement matrix and photocatalytic efficiency to be improved. Shen et al. [44] proposed mixing cement with various nanoparticles $\mathrm{TiO}_{2}$ contents (0 wt. $\%, 2.5 \mathrm{wt} . \%, 5.0 \mathrm{wt} . \%$, and $7.5 \mathrm{wt} . \%$ ) by using a ball mill with a diameter of $500 \mathrm{~mm}$ for $30 \mathrm{~min}$. Of all the methods mentioned above, the ball milling method is highlighted in this research in the mixing stage for better distribution of nanoparticles photocatalyst. Next, the following section discusses about photocatalytic materials that are mostly used in the self-cleaning coating industry.

\subsection{Photocatalytic Materials}

Nanomaterials have attracted scientists' interest extensively and have become a hot topic in the field of research and development due to the new potential particle usage within less than 100 nanometres $(<100 \mathrm{~nm})$, which is nanoscale sized. Therefore, in the future, nanomaterials are considered as the most promising materials $[59,60]$. Nobel laureate Feynman first introduced nanotechnology in 1960. Since then and until now, nanotechnology has become a main topic in research scope and is applied in various engineering fields, for instance, electronics, mechanics, medicals, biomechanics, and coating in building materials. However, since the middle of the 1990s, the application of nanotechnology focused on the construction industry and building materials, which continue to grow from research areas worldwide, which led towards the development of introducing new materials into existing materials [12,33]. The use of nanomaterials as photocatalysts in the cement industry is an innovation that provides a long-term solution to environmentally friendly and recognised green building constructions [61].

Nanomaterials are new materials that have emerged and been utilized for enhancing mechanical strength and modifying the properties of cementitious materials. In these recent years, in order to apply nanotechnology in construction and building materials, research has been extensively conducted on the effects of the addition of nanoparticles towards properties of cementitious materials [58]. With the implementation of nanomaterials in construction and building materials, other types of features and additional new functionalities properties have been developed, such as self-cleaning, anti-bactericidal, anti-microbial, anti-fogging, self-sensing capabilities, depollution, air quality improvement, air decontamination, and discoloration resistance $[12,31,62,63]$.

Nanoparticles of photocatalysts are applied in construction materials, especially in paste, mortar, concrete, cement, paints, pavement, glass, etc., to enhance the properties of self-cleaning and improve the cement properties performance. Nanoparticles have been chosen due owing to their properties on cementitious materials, which are high reactivity, ultrafine size of particle, and unique physical and chemical properties and specific functional properties. In addition, nanomaterials are very reactive because they have a high specific surface, which shows a great potential in improving the mechanical and durability properties of the reaction product [41]. The nanotechnology implementation in cement-based materials has attracted much attention due to the unique properties of nanomaterials and its beneficial effects, which can enhance the performance of concrete properties in terms of gaining strength and functional properties [14,59].

The incorporation of nanomaterials improves structural efficiency and cementitious materials' durability, which assist in the quality improvement and structures' longevity [31]. Nanoparticles added to cement can be used as a cement paste admixture or to replace a portion of the cement, making a significant contribution to the construction materials field $[19,64]$. The well-distributed nanoparticles act as fillers in the empty space, increasing hydration rate and tendency for agglomeration during mixing. Nanoparticles photocatalyst fills up the voids between cement particles and then produces smaller pores in order to increase the strength, modify the properties, and improve mechanical, durability, thermal, and electrical properties of cementitious materials [45]. 
Nanoparticles act as a nano-reinforcement and as a nano-filler and also lead to denser microstructure, thus reducing porosity $[19,27,57]$. Nanoparticles that are studied by researchers and commonly used in cement products to improve their properties are $\mathrm{SiO}_{2}$, $\mathrm{ZnO}, \mathrm{TiO}_{2}$, alumina or aluminium oxide $\left(\mathrm{Al}_{2} \mathrm{O}_{3}\right)$, zirconium dioxide $\left(\mathrm{ZrO}_{2}\right)$, chromium (III) oxide $\left(\mathrm{Cr}_{2} \mathrm{O}_{3}\right)$, and carbon nanotubes $[29,31,33,65,66]$. However, utilization of titania and $\mathrm{ZnO}$ nanoparticles in construction materials is the topic that is most extensively being studied and recently suggested. This is because both of those metal oxides have photocatalytic properties that contribute towards environmental pollution remediation [66].

Technology of photocatalytic materials contribute to the mitigation of pollution due to the presence of sunlight or other ultraviolet light sources, which provide energy to the photocatalytic components, then converting them into harmless substances and serving as self-cleaning material. Among the photocatalysts, $\mathrm{TiO}_{2}$ nanoparticles is one of the most widely utilized in photocatalysis due to the highest photocatalytic activity [29]. Photocatalytic reactions occur when nanoparticles were incorporated into cementitious matrices [12]. Other than $\mathrm{TiO}_{2}$ nanoparticles, zinc oxide has also been reported to exhibit excellent photocatalytic properties. On the other hand, concrete that contains high dosage of nanoparticles has an obvious effect on MB degradation, which is a higher degradation ratio than the lower dosage of nanoparticles [44].

Li et al. [61] discovered that the nanoparticles incorporation into modified cementitious composites contribute to the significant improvement in the microstructures of cementitious composites, resulting in multifunctionality and also improvement of the durability and brittleness of cementitious composites. The durability of concrete was improved when nanoparticles were added because the permeability of the concrete to ions was reduced, resulting in increased concrete strength and reduced porosity [31]. The beneficial action of the nanoparticles in terms of microstructure and performance of cement-based materials was revealed by the roles of nanoparticles that act as fillers in the empty space and fill up the voids between grains of cement, resulting in the well-dispersed nanoparticles acting as centres of crystallization of cement hydrates products in dense structure, hence increasing the rate of hydration. Nanoparticles aided the formation of small-sized calcium hydroxide $\left(\mathrm{Ca}(\mathrm{OH})_{2}\right)$ crystals and homogeneous clusters $\mathrm{C}-\mathrm{S}-\mathrm{H}$ gel, which improved the transition zone structure between aggregates and paste, resulting in good bonding between aggregates and cement paste and nanoparticles that provide crack and interlocking effects between the slip planes, resulting in improved shear, toughness, tensile, and flexural strength of cement-based materials $[64,66]$.

Chen at al. [21] revealed that the nano- $\mathrm{SiO}_{2}$ plays a role as a filler of pores in order to provide sites for nucleation and microstructure modification. Besides, it is also an agent for promoting pozzolanic reaction due to its considerable surface activity. On the other hand, there are also several studies reporting the addition of nano- $\mathrm{Fe}_{2} \mathrm{O}_{3}$ and nano- $\mathrm{Al}_{2} \mathrm{O}_{3}$ into concrete improve compressive and flexural strengths as the interfacial transition zone becomes compact. The results demonstrated that the change of pore structure and the improvement of compressive strength are caused by micro-filling on fine powders. By adding nano- $\mathrm{TiO}_{2}$ into cement-based materials, it affects the hydration degree at early hydration period, which is enhanced with small dosages of nano- $\mathrm{TiO}_{2}$. Additionally, porosity of $\mathrm{TiO}_{2}$ blended pastes was decreased, and the pore volume was reduced mainly within the capillary pore range. Meanwhile, at early ages, compressive strength of the $\mathrm{TiO}_{2}$ blended paste was significantly improved, and shorter setting times as short as that of nano- $\mathrm{TiO}_{2}$ particles were obtained. The author confirmed that nano- $-\mathrm{TiO}_{2}$ is a non-reactive fine filler that has no pozzolanic activity and has a potential to be a nucleation site for the accumulation of hydration products. The nano- $\mathrm{TiO}_{2}$ also had a catalytic effect on the reaction of cement hydration when it was mixed into cement-based materials [21].

There is a new discovery by a researcher on the combination of waste materials (e.g., fly ash) with nanoparticles, shown through the mechanical properties improvement and alteration of microstructure of concrete was altered [19]. Another study found that adding nanomaterials of multi-walled carbon nanotubes to a mixture of Portland cement and fly 
ash increased the strength of the mixture. This is due to the ultra-fine particle properties, which act as filler and give a better result for hydration reaction [33]. Other than that, utilization of nanoscale in industrial waste-based cement replacements contributes to the reduction of carbon dioxide emissions [31]. Thus, there is still ongoing research on the development of nanomaterials to be used with industrial waste products in order to improve its properties. Additionally, nanoparticles of $\mathrm{SiO}_{2}$ are one of the photocatalyst materials commonly being used by most researchers and are discussed in next section.

\subsubsection{Silicon Oxide Nanoparticles}

The nano silica (nano- $\mathrm{SiO}_{2}$ ) plays a role as a pore filler in order to provide nucleation sites and modify the microstructure and as also an agent to promote pozzolanic reaction due to its considerable surface activity. On the other hand, there are also several studies reporting that the addition of nano iron oxide $\left(\mathrm{Fe}_{2} \mathrm{O}_{3}\right)$ and nano alumina oxide $\left(\mathrm{Al}_{2} \mathrm{O}_{3}\right)$ into concrete improves compressive and flexural strengths due to the compaction of interfacial transition zone. The results demonstrated that the change of pore structure and the improvement of compressive strength are caused by micro-filling effect of fine powders [21].

A researcher reported that the pozzolanic activity and compressive strength of mortar containing nano- $\mathrm{SiO}_{2}$ is much higher than mortar containing silica fume [67]. Recent study reported that nano- $\mathrm{SiO}_{2}$ can improve the mechanical properties and durability properties of concrete, resulting in a more refined porous structure and increased resistance to chloride penetration. It also demonstrated an improvement in the mechanical properties of these cementitious mixes [41]. Another author reported that the compressive strength of mortars with nano- $\mathrm{SiO}_{2}$ particles is higher than mortar containing silica fume [2]. Thus, $\mathrm{ZnO}$ nanoparticles also are one of the best self-cleaning agents and are discussed in next section.

\subsubsection{Zinc Oxide Nanoparticles}

Zinc oxide nanoparticles as a photocatalyst have high potential in applications of selfcleaning. The $\mathrm{ZnO}$ nanoparticles as an additive material affect setting time, compressive strength, and cement hydration [33]. ZnO has been chosen as photocatalyst because it has high photocatalytic activity and photocatalytic degradation of organic compounds and highly resists microorganisms. Among other nanoparticles investigated, $\mathrm{ZnO}$ has been identified to be used as alternative to titania due to the photoluminescence properties and unique photocatalytic materials. Zinc oxide nanoparticles are a versatile inorganic semiconductor material and a photocatalyst representative among semiconductors that has a direct band gap ( $3.3 \mathrm{eV}$ at room temperature) and is able to absorb a larger energy fraction of the solar spectrum and more light quanta $[33,65,68]$. The nanoparticles of $\mathrm{ZnO}$ are widely used in many products and materials, such as glass, plastics, paints, and ceramics. Additionally, nano- $\mathrm{ZnO}$ was also utilized for photodegradation of pollutants in concrete [33].

Similar to photocatalyst of $\mathrm{TiO}_{2}$, nano- $\mathrm{ZnO}$ as a nano-photocatalyst has great potential to be applied as self-cleaning in concrete structures due to the effects on the setting time, cement hydration, and compressive strength. The results indicate that, through partial addition of $\mathrm{ZnO}$ in Portland cement pastes, the setting time period was prolonged. In terms of compressive strength, mixing of $\mathrm{ZnO}$ up to $15 \%$ obtained the highest strength at 28 days via filler effect. Nochaiya et al. [33] explained the zinc ions effects on the hydration reaction and the microstructure of hydration products. In addition, the hydration heat was found to decrease when zinc oxide was incorporated with OPC. This is because the cement hydration was retarded, caused by zinc through the layer of amorphous zinc hydroxide $\left(\mathrm{Zn}(\mathrm{OH})_{2}\right)$ and / or crystalline $\mathrm{CaZn}_{2}(\mathrm{OH})_{6} 2 \mathrm{H}_{2} \mathrm{O}$ formation around the anhydrous cement grains. The effect of nano- $\mathrm{ZnO}$ on rheological behaviour of cement pastes was investigated by Ghafari et al. [66].

Liu et al. [67] found that zinc oxide led to the decrement of compressive strength of the sample. In contrast, Nochaiya et al. [33] reported that the compressive strength increases, 
and physical properties of concrete were improved as the amount of $\mathrm{ZnO}$ as an additive material was increased ( $1 \mathrm{wt} . \%, 2 \mathrm{wt} . \%$, and $5 \mathrm{wt} . \%$ ) at 28 days. From microstructural study, it was also described that nano-sized particles do not only act as fillers but also as an activator in order to promote hydration. The photocatalysis of $\mathrm{ZnO}$ powder depends on crystallinity. Portland cement with addition $\mathrm{ZnO}$ nanoparticles has higher compressive strength than conventional concrete. Furthermore, zinc peroxide nanoparticles $\left(\mathrm{ZnO}_{2}\right)$ also could improve the mechanical and physical properties of concrete [33]. Nevertheless, there are only a few reports on the incorporation of $\mathrm{ZnO}$ onto geopolymer materials, especially in nano size. There is limited information on the characterization of $\mathrm{ZnO}$ nanoparticles and its effect on physical-chemical properties in geopolymer structure. Consequently, the research on the effect of zinc oxide nanoparticles in enhancing self-cleaning properties has to be explored. The next section discusses about titanium oxide nanoparticles that are mostly being used as a photocatalyst.

\subsubsection{Titanium Oxide Nanoparticles}

Titanium is the world's fourth most abundant metal and the ninth most abundant metallic element, made up about $0.63 \%$ of the earth's crust. Properties of titanium are high melting point, which is about $1668{ }^{\circ} \mathrm{C}$, and low density, which is $4.5 \mathrm{~g} / \mathrm{cm}^{3}$. Titanium is a metal that is hard, ductile, malleable, and lustrous. Titanium oxide, with chemical formula $\mathrm{TiO}_{2}$ or known as titania, is one of the natural oxides of titanium; it is also called rutile titanium white. It appears in white and silver-grey materials in nature. In solid state, $\mathrm{TiO}_{2}$ exists in the form of three most common crystalline phases, namely rutile (tetragonal), anatase (tetragonal), and brookite (orthorhombic) [20,24,26,29,60,69]. Rutile is made up of pure $\mathrm{TiO}_{2}$ and is used as a pigment in white paints with low photocatalytic reactivity, whereas anatase is the most active photocatalyst and is more widely used [20].

Meanwhile, the brookite phase is rarely used because of its structural instability and unusual morphology, which is generated during the titanium ore weathering process [61]. In comparison to rutile, anatase is the most preferable phase for photocatalytic reactions because of its high reactivity, stability, large surface area, and higher activity [26,69]. The high photocatalytic efficiency of anatase is due to the low specific surface areas and interface reaction of photocatalysis [39].

Besides the high photocatalytic efficiency of $\mathrm{TiO}_{2}$, anatase is suitable for the photocatalytic degradation process due to its chemically stable, inexpensive, unreactive metal oxide, non-toxic materials, and semiconductors characteristics [24,26]. $\mathrm{TiO}_{2}$ is used in daily products, such as in toothpaste, sunscreen, paint, plastics, cosmetics, foodstuff, glasses, textiles, tiles, etc. Glasses, windows, or tiles are modified with the addition of $\mathrm{TiO}_{2}$ as a photocatalytic thin film for their self-cleaning functions, which have been applied in the glass surface of the National Opera Hall, China. In Japan, eco-friendly, self-cleaning windows and roof tiles are widely used. Japan and Europe have been using this technology to ensure that their polluted cities are kept clean, and the effect of air pollution is mitigated $[15,18,21,25,70]$.

Towards the end of the $1980 \mathrm{~s}, \mathrm{TiO}_{2}$ began to be applied as photocatalyst in construction materials $[15,23]$. The interest to combining $\mathrm{TiO}_{2}$ photocatalysts with cementitious materials has received considerable research and is growing rapidly to produce photocatalytic functional products [21,49]. Due to its unique properties, such as anti-corrosion, safety, high photocatalytic activity, compatibility with conventional construction materials (e.g., cement, without affecting original performance), and effectiveness in ambient atmospheric environment under weak solar irradiation, $\mathrm{TiO}_{2}$ is widely used in photocatalytic building materials [15]. In the field of photocatalytic construction and building materials, the versatile function of $\mathrm{TiO}_{2}$ is that it serves as photocatalytic materials, coating materials, and structural materials, which has facilitated its application in exterior construction materials and interior furnishing materials, such as concrete, cement mortar, paving blocks, pavement, stucco, glass, window, polyvinyl chloride (PVC) fabric, and ceramic tiles [21,24,27,71]. 
This can be seen through the roof of Dubai Sports City's Cricket Stadium, which has been coated white cement containing $\mathrm{TiO}_{2}$ nanoparticles, and it has also used for designing a church at Rome, Italy. It was proven that the buildings keep their original colour over the years $[16,26]$. On the other hand, more recently, the use of $\mathrm{TiO}_{2}$ in nano-sized as a zero-dimensional nanomaterial has received widespread and special attention from both industry and research studies in the cementitious materials field for the production of self-cleaning concrete, photocatalytic concrete, smog-eating concrete, or green concrete [24].

The self-cleaning effect is due to the photo-induced superhydrophilicity and the photocatalytic reaction of nanoparticles $\mathrm{TiO}_{2}$ that was activated by the UV light radiation. Furthermore, nano- $\mathrm{TiO}_{2}$ appears in form of spherical or ellipsoidal that enhances photocatalytic activity. There is increasing interest in using photocatalyst in cementitious materials due to their strong binding property, which can immobilize nano- $\mathrm{TiO}_{2}$ powders within their matrices. Much research work demonstrated that nano- $\mathrm{TiO}_{2}$ could modify material structures and influence physical and chemical properties for the development of high-performance, durable, multifunctional, and environmentally friendly cementitious composites $[25,28,60]$.

It was believed that the addition of nano- $\mathrm{TiO}_{2}$ as photocatalyst into cement-based material has won great attention and wide applications in large-scale due to its features in terms of chemical stability, high photocatalytic activity, low price, easy availability, high dielectric constant, weather ability, antimicrobial prosperities, and stability under UV radiation, and the problem of urban air pollutants was solved due to its self-cleaning, self-disinfecting, and air purifying properties, contributing to the environmental pollution cleansing $[20,21,53,72,73]$.

Titanium oxide has excellent ultraviolet (UV) resistant qualities and is used as sunscreen in cosmetics due to its absorption of UV light without being consumed in the reaction $[24,70]$. Under exposure to sunlight, $\mathrm{TiO}_{2}$ photocatalytic reaction is activated by UV radiation $(\lambda<390 \mathrm{~nm}$ ) to oxidize decomposition of organic materials (such as dirt, soot, grime, oil, and particulates), biological organisms (mould, algae, bacteria, and allergens), airborne pollutants (VOC, tobacco smoke, NOx, and SOx), and materials broken down into simple molecules, such as oxygen, carbon dioxide, water, sulphate, nitrate, and other inorganic compounds. The $\mathrm{TiO}_{2}$ is not consumed in the reaction; thus, it can be used definitely endlessly [59,70]. Other than that, the $\mathrm{TiO}_{2}$ photocatalyst naturally decomposes gaseous pollutants and reduces $\mathrm{NOx}$ in the atmosphere $[29,70]$. $\mathrm{TiO}_{2}$ is photocatalyst for the photocatalytic oxidation process and is the most suitable as a semiconducting material in making use of the UV-A part of sunlight for the $\mathrm{NOx}$ chemical conversion. $\mathrm{TiO}_{2}$ photocatalysis also performed even in weak UV light [37,70].

Cardenas et al. [27] and Jayapalan et al. [63] focused on the depollution activity of cement pastes with the addition of nano- $\mathrm{TiO}_{2}(0 \%, 0.5 \%, 1.0 \%, 3.0 \%$, and $5.0 \%)$, which were evaluated through the degradation of pollutants. The author preferred to choose nitrogen oxides, $\mathrm{NOx}\left(\mathrm{NO}+\mathrm{NO}_{2}\right)$, as a pollutant in the form of photochemical smog because it causes serious environmental problem (i.e., asthma and lung problems) and contributes to the acid rain, which is harmful for forests, crops, and aquatic life. The degradation of NOx, also known as deNOx-process or depollution, which purifies photocatalytic surfaces the environmental air at two different aging times, $65 \mathrm{~h}$ and 28 days, respectively, shows the best photocatalytic activity at early age $[26,27,69]$.

In certain cases, the anatase $\mathrm{TiO}_{2}$ addition leads for the mechanical performance decrement and durability of the concrete [46]. The porous structure of the hardened cement pastes or mortars increases due to the imparting $\mathrm{TiO}_{2}$ particles and other photo-oxidation products. In contrast, the total porosity of the cement pastes decreased due to alteration of distribution pore size and shortening initial and final setting time due to the nano- $\mathrm{TiO}_{2}$ addition [21]. Ratan and Saini [30] studied the related utilization of nanosized- $\mathrm{TiO}_{2}$ for the production of self-cleaning white cement and found that there is also a drawback in usage of $\mathrm{TiO}_{2}$ nanoparticles, which is that nano- $\mathrm{TiO}_{2}$ tends to agglomerate in the cementitious material. However, these drawbacks are not a reason to replace nanosized- $\mathrm{TiO}_{2}$ with microsized- $\mathrm{TiO}_{2}$, 
as the reduction in the photoactivity of self-cleaning cement is the major disadvantage of $\mathrm{TiO}_{2}$ in micro sizes. Ref. [31] stated that the use of $\mathrm{TiO}_{2}$ nanoparticles significantly increased the photoactivity of $\mathrm{TiO}_{2}$-containing cements rather than larger $\mathrm{TiO}_{2}$ particles.

The addition of $\mathrm{TiO}_{2}$ powder to cement mixes significantly affects the cement hydration rate and the properties of cement pastes and mortars. The author revealed that, during the hydration process, $\mathrm{TiO}_{2}$ was inert and stable because the variation of relative mass ratios at different curing ages was very small. By increasing the concentration of $\mathrm{TiO}_{2}$, photocatalytic activity also increased due to more $\mathrm{TiO}_{2}$ deposition on the surface of hydration products and fine aggregates. Nevertheless, the higher $\mathrm{TiO}_{2}$ concentration stirred up an agglomeration problem of $\mathrm{TiO}_{2}$, which led to more recombination of electron-holes and difficulties for $\mathrm{TiO}_{2}$ particles to be exposed to the photocatalytic reaction [69].

Many studies have found that nano- $\mathrm{TiO}_{2}$ acts as a catalyst in cement hydration reactions, resulting in a significant increase in the rate of early-age hydration of cementitious materials and a change in microstructure, which affects the physical and mechanical properties of cement-based materials. The mortar's compressive strength was improved at an early age, and it improved the abrasion resistance of concrete as well as the pore-refining effect $[13,21,49]$. However, the early-age mechanical properties of the geopolymer product with the $\mathrm{TiO}_{2}$ nanoparticles addition increased as the addition dosage of $\mathrm{TiO}_{2}$ nanoparticles increased up to $10 \%$ by cement weight, and the later-age mechanical properties were decreased. This is due to the nanoparticles tending to agglomerate at higher dosages [54].

Effects of nano- $\mathrm{TiO}_{2}$ on the mechanical properties of cement mortar was studied by Meng et al. [71]; when cement mortar was substituted by nano- $\mathrm{TiO}_{2}$, the strength of cement mortar at early ages increased due to the decrease and modification of the orientation index. Meanwhile, strength at later ages decreased obviously, and it was useful to modify the fluidity by adding superplasticizer and slag powder into cement mortar. Rakhimova and Rakhimov [10] reported that compressive strength of cement mortar (0 to $20 \mathrm{wt} \%$ addition of $\mathrm{TiO}_{2}$ ) is increased due to pozzolanic activity. Other than that, it is also reported that, by increasing the nanoparticles $\mathrm{TiO}_{2}$ content up to $15 \mathrm{wt} \%$, setting time of fresh mortar and concrete was decreased. The self-cleaning performances of photocatalytic-cementitious materials were evaluated based on the degradation of colour in organic dyes (e.g., methyl orange (MO), Rhodamine B (RhB), and methylene blue (MB)) $[16,44,49]$.

The self-cleaning test is conducted in order to evaluate self-cleaning abilities and depollution effects of the material. Photocatalytic performance is measured by photo degradation of $\mathrm{MB}$ solution or RhB in the concrete surface in order to evaluate self-cleaning activities. The photo-induced bleaching of $\mathrm{MB}$ dye to evaluate photocatalytic materials can be measured using the Ultraviolet-visible spectrophotometer (UV-Vis) [16]. The experimental study on the ability of silicate coating material, which contains various dosages of $\mathrm{TiO}_{2}$ is to clean the surface by itself and for degradation of particulate pollutants. Based on the result of the experiment, an optimum dosage of $\mathrm{TiO}_{2}$ in the silicate coating is $15 \% \mathrm{TiO}_{2}$ by mass of solid silicate in photocatalytic degradation of $\mathrm{RhB}$ [45]. The investigation proved that building materials that re coated with $\mathrm{TiO}_{2}$ re able to remove soot. These are based on colour changes in $\mathrm{RhB}$ samples, and photocatalytic degradation was tested using a closed-chamber experiment [28].

The effect of directly applying $\mathrm{TiO}_{2}$ into clear paint coated on the surface of selfcompacting architectural mortars under Ultraviolet-A (UV-A) and visible light irradiation was studied by Guo et al. [49]. Self-cleaning purpose and weathering-resistant ability were determined by the degradation of RhB. The result shows that properties of selfcleaning improve a building's aesthetic appearance due to high photocatalytic efficiency and weathering resistant; hence, the costs of routine maintenance were reduced [49].

Other than Rhodamine B dye, an author reported that cationic dye methylene blue was easily degraded compared to methyl orange and other dyes because of dye adsorption onto the photocatalyst accelerated the degradation process. Furthermore, MB dye is easily removed by adsorption because it has more affinity to adsorption. Shen et al. [44] revealed that methylene blue was degraded effectively due to the ultra-smooth surface 
and photocatalytic properties, which are to be utilized as a self-cleaning finishing material for urban buildings (as shown in Figure 3). As a result, the residue of contaminants was washed away by the rain. The photocatalytic activities of the nanosheets were evaluated in terms of ability to degrade dye of methylene blue [16]. In addition, the second part of this review discusses the potential of a geopolymer to be applied as self-cleaning coating.

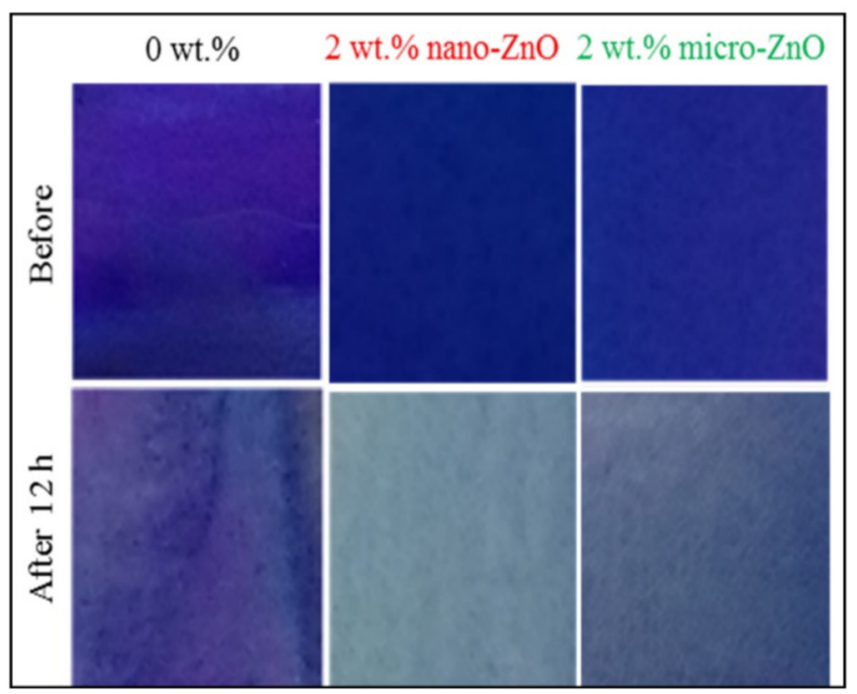

Figure 3. Photocatalytic effect on self-cleaning composite with the function of time under UV exposure [73].

\section{Geopolymer \\ Geopolymer Paste}

Geopolymers have been manufactured as paste, mortar, and concrete [74]. For finishing materials, geopolymer paste has been chosen to be applied in the outer wall of the building. Geopolymer paste is a hardened cementitious paste that combines waste products into useful product. The reaction between source material that has higher content of silica and alumina with alkaline liquid results to form a geopolymer paste [74,75]. For testing purpose, the prepared geopolymer paste was cast into a mould and cured at ambient temperature without elevated heat for hardening and for the geopolymerization process to occur. The development mixtures of geopolymer are suitable for curing at room temperature, which was the extent of its application [76].

However, based on published literature, fly ash is most commonly chosen as a base for geopolymer paste. There is a study on fly ash-based geopolymer containing low calcium, which was cured in ambient temperature $\left(23^{\circ} \mathrm{C}\right)$ without additional heat, and the results show that geopolymer mixtures are suitable for ambient curing, as the condition of the moisturized specimens after hardening was improved and under control [74]. However, in certain cases, geopolymer paste was cured at the required temperature for a specific time in order to be applied in construction materials, especially for precast concrete applications [76-79].

Geopolymer paste demonstrates various advantages in terms of properties and characteristics, including sustainable high mechanical strength, which is gained in a short time; excellent durability; low shrinkage; and high temperature resistance and acid resistance, which is in contrast with OPC $[74,80,81]$. Geopolymers are ideal for applications in building, repairing infrastructures, and also pre-casting due to high early strength properties and remaining intact under exposure for a long time, and setting time could be controlled [80].The mechanical strength of geopolymer paste was believed to increase by considering the reaction amounts of combination between $\mathrm{SiO}_{2}$ and $\mathrm{Al}_{2} \mathrm{O}_{3}$ in the fly ash. An experimental result shows that the $\mathrm{Si} / \mathrm{Al}$ ratio has a significant impact on the compressive strength of geopolymer paste [79]. Other authors reported that there are other parameters that 
affect the compressive strength of geopolymer paste, such as the ratio of fly ash to alkaline activator (solid-to-liquid ratio) and the ratio of alkaline activator $\left(\mathrm{Na}_{2} \mathrm{SiO}_{3} / \mathrm{NaOH}\right)$, which had a greater influence on the strength. Thus, the research related to the solid-to-liquid ratio with a range of 2.5 to 3.3 and a ratio of sodium silicate to $\mathrm{NaOH}$ in the range of 0.4 to 2.5 was investigated. The results demonstrate that the optimum solid-to-liquid ratio is 2 , while the optimum ratio of alkaline activator is 2.5 , as the maximum compressive strength was achieved at this ratio, respectively [5].

The strength development of the geopolymer paste is also affected by aluminosilicate or geopolymer gel formation. The existence of the aluminosilicate or the geopolymer gel can be identified in X-ray diffraction (XRD) pattern of geopolymer paste, which is from the broad hump peaks around $20^{\circ}$ to $40^{\circ}$ of 2 theta with high intensity, as shown in Figure 4 [82].

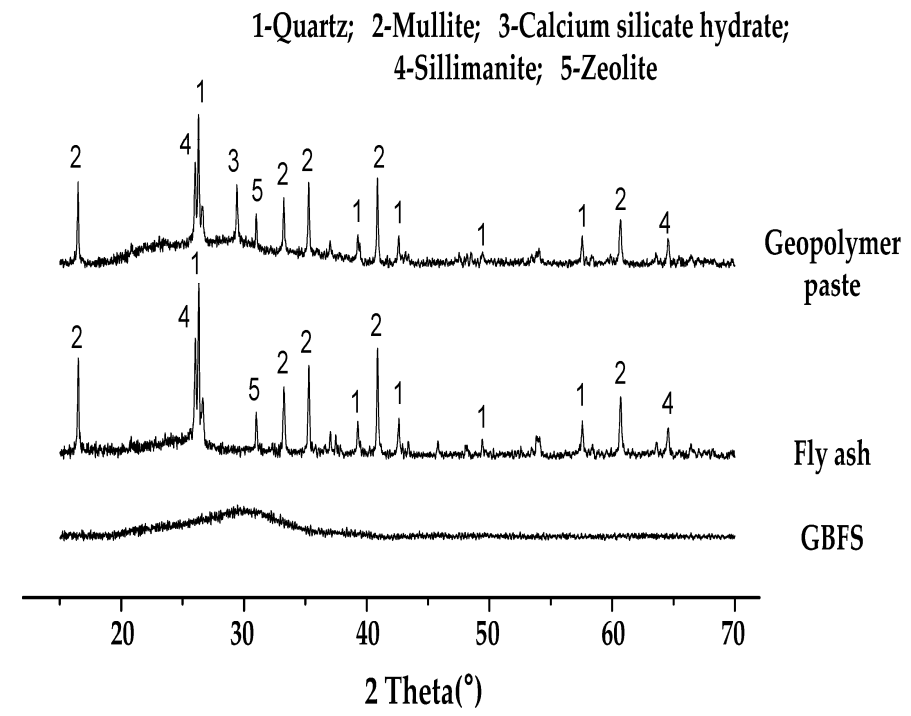

Figure 4. XRD pattern of geopolymer paste and raw materials [82].

The polymerization reactivity and the strength development of geopolymer paste can be observed through scanning electron microscope (SEM) [79]. The microstructure of aluminosilicate gel, which develops from the solution formed due to partial dissolution of fly ash in alkali solution, underwent changes due to the $\mathrm{Si} / \mathrm{Al}$ and $\mathrm{Na} / \mathrm{Al}$ ratios.

SEM result revealed that (as shown in Figure 5) the main reaction product in alkaliactivated fly ash is to form calcium silicate hydrate gel (C-S-H), calcium aluminate hydrate gel (C-A-H), calcium aluminium silicate gel (C-A-S-H), or sodium aluminosilicate hydrate gel (N-A-S-H) $\left(\mathrm{C}=\mathrm{CaO}, \mathrm{N}=\mathrm{Na}_{2} \mathrm{O}, \mathrm{A}=\mathrm{Al}_{2} \mathrm{O}_{3}, \mathrm{~S}=\mathrm{SiO}_{2}, \mathrm{H}=\mathrm{H}_{2} \mathrm{O}\right)$ [7]. Additionally, the fly ash-based geopolymer paste has been partially replaced or blended with a small amounts of various additives supplementary cementing materials (e.g., silica fume, metakaolin, rice husk ash and ground granulated blast-furnace slag), and their effects have been studied by several researchers in order to accelerate the reaction at early-age properties and enhance durability performance $[76,80]$. 


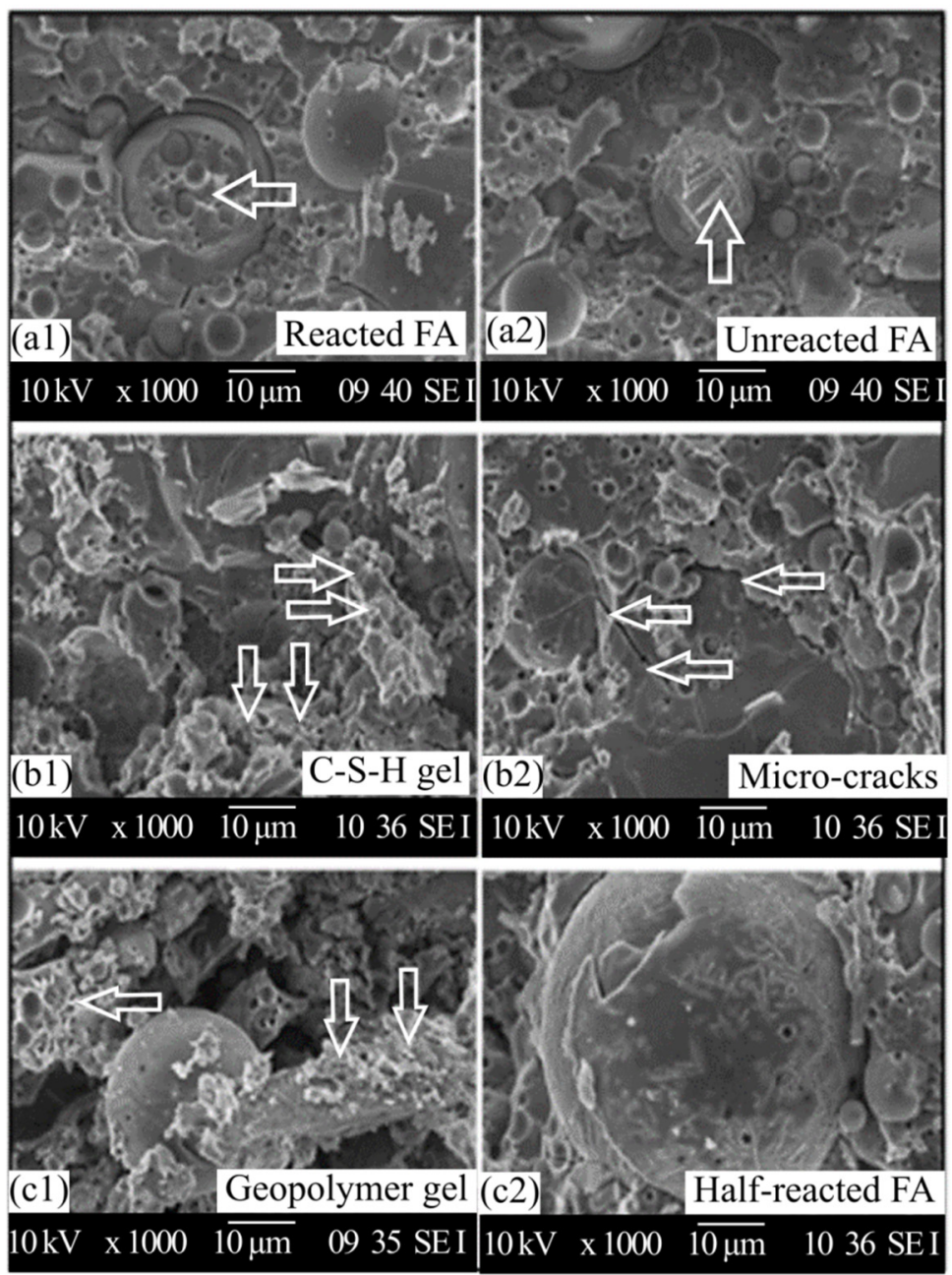

Figure 5. SEM images fly ash-based geopolymer paste [7].

Duan et al. [43] aimed at investigating the effects of nano- $\mathrm{TiO}_{2}$ addition into fluidized bed fly ash-based geopolymer on properties including compressive strength, drying shrinkage, carbonation, and microstructure. The geopolymer sample was prepared through alkali activation of sodium silicate and sodium hydroxide solutions that are cured in microwave radiation environment and heat curing period, then aged for 28 days. The experimental results demonstrated that the addition of $\mathrm{TiO}_{2}$ enhances compressive strength of geopolymer with the increasing content of nano- $\mathrm{TiO}_{2}$ at both the early and later age, which is obvious when $5 \%$ nano- $\mathrm{TiO}_{2}$ is introduced into geopolymer paste. In terms of microstructure analysis, the addition of nano- $\mathrm{TiO}_{2}$ promotes the formation of geopolymer and results in compact microstructure with lesser cracks, as shown in Figure 6. The effect of incorporating nano- $\mathrm{TiO}_{2}$ improves carbonation resistance and reduces geopolymer drying shrinkage [43]. 


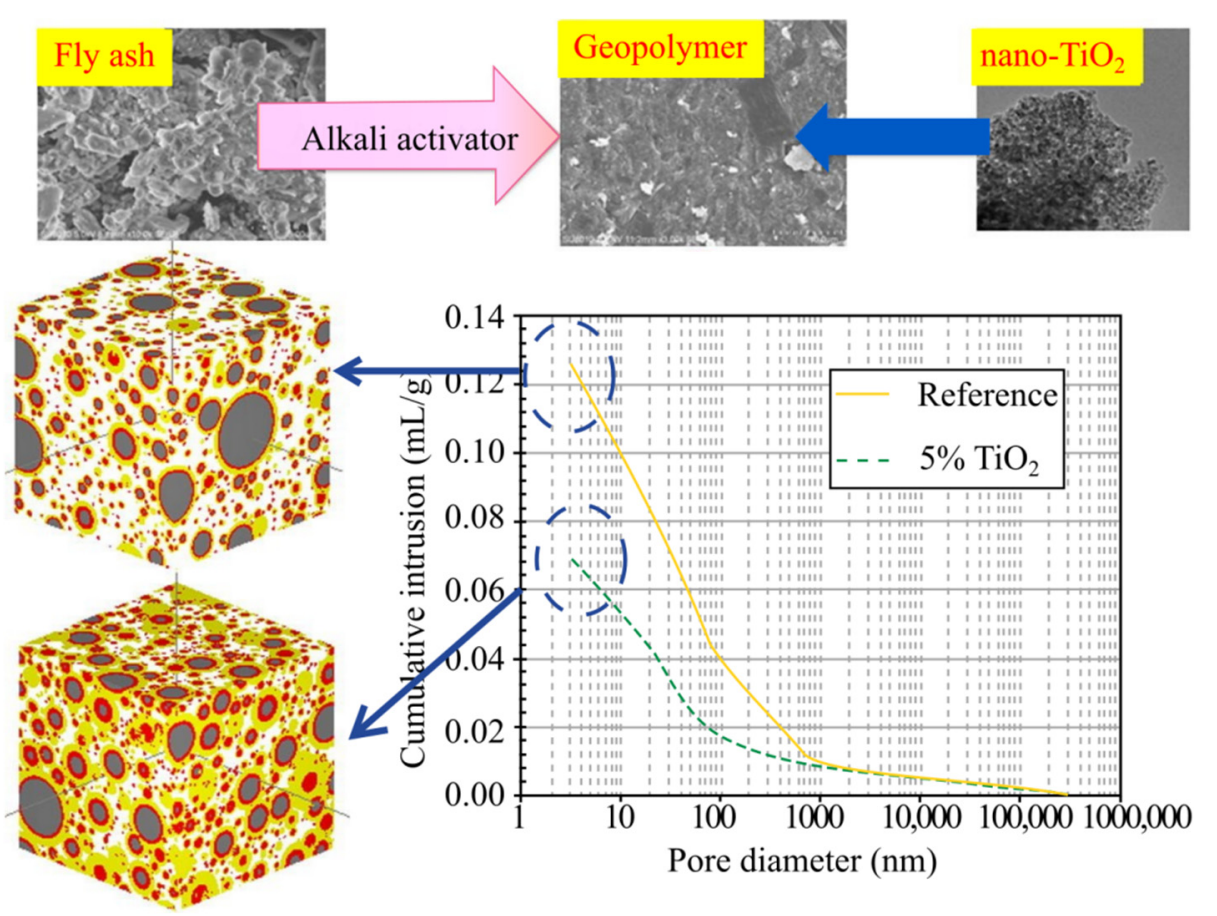

Figure 6. Microstructure formation of geopolymer paste with photocatalyst. Reprinted with permission from ref. [43]. Copyright Elsevier, 2016.

Other researchers reported that all samples of $\mathrm{TiO}_{2}$ in cementitious materials by activated zeolite fly ash bead carrier $\left(\mathrm{ZFAB} / \mathrm{TiO}_{2}\right)$ yielded better photocatalytic effects at higher efficiency and longer-term performance than samples with pure $\mathrm{TiO}_{2}$. This could reduce the risks of cement hydrates on $\mathrm{TiO}_{2}$ particles. Moreover, with increasing dosage of $\mathrm{ZFAB} / \mathrm{TiO}_{2}$, the photocatalytic effects also increased. The mechanism of long-term photocatalytic cementitious materials is illustrated in schematic diagram, as shown in Figure 7 [57].

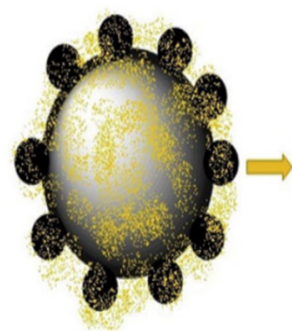

$\mathrm{ZFAB} / \mathrm{TiO}_{2}$

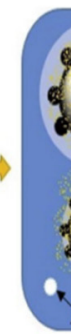

Air

Fresh photocatalytic

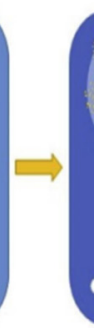

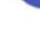
Carbonized photocatalytic cementitious material

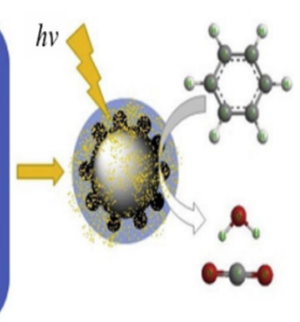

Photocatalytic reaction

$$
\text { ZFAB } \mathrm{TiO}_{2} \text { agglomerates } \quad \begin{aligned}
& \text { Low Ca element cement hydrates } \\
& \text { in } \mathrm{ZFAB} / \mathrm{TiO}_{2} \text { surface }
\end{aligned}
$$

Figure 7. Mechanism of long-term photocatalytic cementitious materials. Reprinted with permission from ref. [57]. Copyright Elsevier, 2016.

Yang et al. [57] stated that the addition of $\mathrm{TiO}_{2}$ nanoparticles enhances the reaction products formation, which results in less cracks and dense microstructure of alkali-activated slag paste. The same effects of nanoparticles addition have been reported by Guerrero et al. [83], where geopolymer systems were enhanced with nano- $\mathrm{TiO}_{2}$ as a micro-filler in geopolymer matrix, which became denser with reaction products that helped to reduce cracks and improved compressive strength. In self-cleaning aspect, $1 \%$ nano- $\mathrm{TiO}_{2}$ was remarked as an optimum dosage by showing higher percentage of Rhodamine b degradation 
in alkali-activated materials (based of blended metakaolin and ground granulated blast furnace slag) [83]. In the same work conducted by the author, self-cleaning testing was examined through the immersion of the sample in red clay solution for several minutes; then, the result after the sample was taken out so that there was no dirt or clay particulates on the surface of the sample [84].

In XRD and fourier-transform infrared spectroscopy (FTIR) analyses, there were a few researchers who stated that the results only indicate the geopolymerization or alkali activation process and no new phase formation except for the appearance of additional mineral anatase [83,85]. Sastry et al. [85] reported that the fly ash-based geopolymer concrete mixed alkaline activator ratio at 2.5 with $5 \%$ nano- $\mathrm{TiO}_{2}$ shows the highest compressive strength than reference sample (without photocatalyst). Due to the addition of $\mathrm{TiO}_{2}$ photocatalyst, the water absorption of low-calcium fly ash geopolymer concrete was reduced and led to the formation of additional reactive products, which causes the geopolymer matrix to become denser, as confirmed through XRD and SEM analyses [85]. Based on the literature, there is still limited study in utilizing the nanoparticles $\mathrm{TiO}_{2}$ in geopolymer paste for self-cleaning applications. The purposes of applying the self-cleaning materials are to improve physical and mechanical properties as well as photocatalytic activity, resulting in a depollution effect for the products. Nonetheless, there are a few reports on the addition of nanoparticles to geopolymer paste that have yet to be published.

\section{Summary and Future Works}

From the review that has been done, there are a few things that can be concluded. Firstly, past studies on conventional cement that applied the self-cleaning concept showed better performance in terms of physical, mechanical, and self-cleaning properties. This was due to the unique properties of photocatalyst that has been added into it, which contributed to better performance. Meanwhile, in certain cases, the strength was decreased when the dosage of nanoparticles photocatalyst increased. Other than that, physical properties of cement based photocatalyst were altered by the nanoparticle's filler.

To overcome all of the issues, the innovation from conventional cement to the green cementitious materials by using by-product materials was introduced. Therefore, the idea of using nanoparticles as photocatalyst in a fly ash-based geopolymer paste to create novel self-cleaning geopolymer materials with improved strength, physical, and photocatalytic properties has been proposed. Thus, reviews were conducted on the geopolymer paste, which has the potential to be used as a self-cleaning agent. The impact of adding photocatalyst on physical-mechanical properties in the application of geopolymer paste in the field work has been discussed in depth. The result shows that nanoparticles materials are valid to be used as a photocatalyst for the geopolymer. However, based on a limited experimental study, there is a lack of studies on the use of geopolymers as self-cleaning materials. Only a few researchers have studied geopolymer with nanoparticles photocatalyst, but they have only focused on physical and mechanical properties and have not discussed self-cleaning and photocatalytic degradation, among other things.

From the literature reviews, the following research gaps have been identified, and several future works are proposed in this study, as listed below:

- More studies on the optimum dosage of photocatalyst are required due to its influence on physical, mechanical, and photocatalytic properties;

- Studies on doping materials in order to enhance or extend the photocatalytic activity and self-cleaning performance under both UV and sunlight;

- Further investigation on the reaction between nanoparticles photocatalyst and geopolymer matrix;

- The geopolymer properties need to be observed based on the mechanical and physical properties depending on the desired application; and

- Research on the photocatalytic activity of self-cleaning geopolymer paste. 


\begin{abstract}
Author Contributions: Conceptualization, S.N.Z., N.M. and M.M.A.B.A.; data curation, S.N.Z., N.M. and D.S.C.H.; formal analysis, S.N.Z., N.M., M.M.A.B.A., P.V. and A.V.S.; investigation, S.N.Z. and N.M.; methodology, S.N.Z., N.M., M.M.A.B.A. and S.Z.A.R.; project administration, N.M., D.S.C.H. and Z.Y.; validation, N.M., M.M.A.B.A., P.V., A.V.S. and Z.Y.; writing of review and editing, S.N.Z., N.M., M.M.A.B.A. and S.Z.A.R. All authors have read and agreed to the published version of the manuscript.

Funding: This study was supported by Center of Excellence Geopolymer and Green Technology (CEGeoGTECH) UniMAP and Faculty of Technology Mechanical Engineering, UniMAP.
\end{abstract}

Institutional Review Board Statement: Not applicable.

Informed Consent Statement: Not applicable.

Data Availability Statement: Not applicable.

Acknowledgments: The authors wish to extent their gratitude for Center of Excellence Geopolymer and Green Technology (CEGeoGTech), Universiti Malaysia Perlis (UniMAP) because of their support with providing all the necessary facilities.

Conflicts of Interest: The authors declare no conflict of interest.

\title{
References
}

1. Purushotham, P.; Prasad, M.H.; Naveen, P. A Study on Green Concrete. Int. Res. J. Eng. Technol. 2017, 4, 601-607.

2. Assi, L.N.; Deaver, E.E.; ElBatanouny, M.K.; Ziehl, P. Investigation of early compressive strength of fly ash-based geopolymer concrete. Constr. Build. Mater. 2016, 112, 807-815. [CrossRef]

3. Abdullah, M.M.A.; Kamarudin, H.; Bnhussain, M.; Nizar, I.K.; Rafiza, A.; Zarina, Y. The Relationship of NaOH Molarity, $\mathrm{Na}_{2} \mathrm{SiO}_{3} / \mathrm{NaOH}$ Ratio, Fly Ash/Alkaline Activator Ratio, and Curing Temperature to the Strength of Fly Ash-Based Geopolymer. Adv. Mater. Res. 2011, 328-330, 1475-1482. [CrossRef]

4. Lucas, S.; Ferreira, V.; de Aguiar, J.B. Incorporation of titanium dioxide nanoparticles in mortars-Influence of microstructure in the hardened state properties and photocatalytic activity. Cem. Concr. Res. 2012, 43, 112-120. [CrossRef]

5. Abdullah, M.M.A.; Hussin, K.; Bnhussain, M.; Razak, R.A.; Yahya, Z. Effect of $\mathrm{Na}_{2} \mathrm{SiO}_{3} / \mathrm{NaOH}$ ratios and $\mathrm{NaOH}$ molarities on compressive strength of fly-ash-based geopolymer. ACI Mater. J. 2012, 109, 503-508.

6. Guo, M.Z.; Ling, T.C.; Poon, C.S. Nano-TiO 2 -based architectural mortar for NO removal and bacteria inactivation: Influence of coating and weathering conditions. Cem. Concr. Compos. 2013, 36, 101-108. [CrossRef]

7. Bouaissi, A.; Li, L.-Y.; Abdullah, M.M.A.B.; Bui, Q.-B. Mechanical properties and microstructure analysis of FA-GGBS-HMNS based geopolymer concrete. Constr. Build. Mater. 2019, 210, 198-209. [CrossRef]

8. Aliabdo, A.A.; Abd Elmoaty, A.E.M.; Salem, H.A. Effect of cement addition, solution resting time and curing characteristics on fly ash based geopolymer concrete performance. Constr. Build. Mater. 2016, 123, 581-593. [CrossRef]

9. Nath, S.; Maitra, S.; Mukherjee, S.; Kumar, S. Microstructural and morphological evolution of fly ash based geopolymers. Constr Build. Mater. 2016, 111, 758-765. [CrossRef]

10. Rakhimova, N.; Rakhimov, R.Z. Toward clean cement technologies: A review on alkali-activated fly-ash cements incorporated with supplementary materials. J. Non-Cryst. Solids 2019, 509, 31-41. [CrossRef]

11. Behfarnia, K.; Azarkeivan, A.; Keivan, A. The Effects of $\mathrm{TiO}_{2}$ and $\mathrm{ZnO}$ Nanoparticles on Physical and Mechanical Properties of Normal Concrete. Asian J. Civ. Eng. 2013, 14, 517-531.

12. Cohen, J.D.; Gallego, G.A.S.; Tobón, J.I. Evaluation of Photocatalytic Properties of Portland Cement Blended with Titanium Oxynitride $\left(\mathrm{TiO}_{2}-\mathrm{xNy}\right)$ Nanoparticles. Coatings 2015, 5, 465-476. [CrossRef]

13. Zhang, R.; Cheng, X.; Hou, P.; Ye, Z. Influences of nano- $\mathrm{TiO}_{2}$ on the properties of cement-based materials: Hydration and drying shrinkage. Constr. Build. Mater. 2015, 81, 35-41. [CrossRef]

14. Ouyang, J.; Han, B.; Cheng, G.; Zhao, L.; Ou, J. A viscosity prediction model for cement paste with nano-SiO 2 particles. Constr. Build. Mater. 2018, 185, 293-301. [CrossRef]

15. Chen, J.; Poon, C.S. Photocatalytic activity of titanium dioxide modified concrete materials-Influence of utilizing recycled glass cullets as aggregates. J. Environ. Manag. 2009, 90, 3436-3442. [CrossRef] [PubMed]

16. Banerjee, S.; Dionysiou, D.D.; Pillai, S.C. Self-cleaning applications of TiO2 by photo-induced hydrophilicity and photocatalysis. Appl. Catal. B Environ. 2015, 176-177, 396-428. [CrossRef]

17. Boonen, E.; Beeldens, A.; Dirkx, I.; Bams, V. Durability of Cementitious Photocatalytic Building Materials. Catal. Today 2017, 287, 196-202. [CrossRef]

18. Khitab, A.; Alam, M.; Riaz, H.; Rauf, S. Smart concretes: Review. Int. J. Adv. Life Sci. Technol. 2014, 1, 47-53. [CrossRef]

19. Vignesh, T.; Sumathi, A.; Mohan, K.S.R. Study on Self-Cleaning Concrete Using Nano-liquid TiO 2 . Int. J. Eng. Technol. 2018, 7, 860-863. [CrossRef]

20. Alfieri, I.; Lorenzi, A.; Ranzenigo, L.; Lazzarini, L.; Predieri, G.; Lottici, P.P. Synthesis and characterization of photocatalytic hydrophobic hybrid $\mathrm{TiO}_{2}-\mathrm{SiO}_{2}$ coatings for building applications. Build. Environ. 2017, 111, 72-79. [CrossRef] 
21. Chen, J.; Kou, S.C.; Poon, C.S. Hydration and properties of nano- $\mathrm{TiO}_{2}$ blended cement composites. Cem. Concr. Compos. 2012, 34, 642-649. [CrossRef]

22. Boonen, E.; Beeldens, A. Photocatalytic roads: From lab tests to real scale applications. Eur. Transp. Res. Rev. 2011, 5, 79-89. [CrossRef]

23. Kumar, J.; Srivastava, A.; Bansal, A. Production of Self-Cleaning Cement Using Modified Titanium Dioxide. Int. J. Innov. Res. Sci. Eng. Technol. 2013, 2, 2688-2693.

24. Patil, J.; Pendharkar, U. Study of Effect of Nanomaterials as Cement Replacement on Physical Properties of Concrete. Int. Res. J. Eng. Technol. 2016, 3, 300-308.

25. Barbesta, M.; Schaffer, D. Concrete that cleans itself and the air: Photocatalytic cement helps oxidize pollutants. Concr. Int. 2009, February, 31-33.

26. Dolatabadi, M.H. Properties and Performance of Photocatalytic Concrete. Master's Thesis, University of Toronto, Ottawa, ON, Canada, 2013; p. 121.

27. Cardenas, C.; Tobon, J.I.; García, C.; Vila, J. Functionalized building materials: Photocatalytic abatement of NOx by cement pastes blended with $\mathrm{TiO}_{2}$ nanoparticles. Constr. Build. Mater. 2012, 36, 820-825. [CrossRef]

28. Smits, M.; Chan, C.K.; Tytgat, T.; Craeye, B.; Costarramone, N.; Lacombe, S.; Lenaerts, S. Photocatalytic degradation of soot deposition: Self-cleaning effect on titanium dioxide coated cementitious materials. Chem. Eng. J. 2013, 222, 411-418. [CrossRef]

29. Jibhenkar, K.B.; Vaidya, V.D.; Waghmare, S.S.; Singh, D.P. Eco-sustainable Pervious Concrete using Titanium Dioxide. Int. J. Sci. Res. Dev. 2015, 3, 391-392.

30. Ratan, J.K.; Saini, A. Enhancement of photocatalytic activity of self-cleaning cement. Mater. Lett. 2019, 244, 178-181. [CrossRef]

31. Hanus, M.J.; Harris, A.T. Nanotechnology innovations for the construction industry. Prog. Mater. Sci. 2013, 58, 1056-1102. [CrossRef]

32. Midtdal, K.; Jelle, B.P. Self-cleaning glazing products: A state-of-the-art review and future research pathways. Sol. Energy Mater. Sol. Cells 2013, 109, 126-141. [CrossRef]

33. Nochaiya, T.; Sekine, Y.; Choopun, S.; Chaipanich, A. Microstructure, characterizations, functionality and compressive strength of cement-based materials using zinc oxide nanoparticles as an additive. J. Alloys Compd. 2015, 630, 1-10. [CrossRef]

34. Petronella, F.; Truppi, A.; Ingrosso, C.; Placido, T.; Striccoli, M.; Curri, M.; Agostiano, A.; Comparelli, R. Nanocomposite materials for photocatalytic degradation of pollutants. Catal. Today 2017, 281, 85-100. [CrossRef]

35. Strini, A.; Roviello, G.; Ricciotti, L.; Ferone, C.; Messina, F.; Schiavi, L.; Corsaro, D.; Cioffi, R. TiO 2 -Based Photocatalytic Geopolymers for Nitric Oxide Degradation. Materials 2016, 9, 513. [CrossRef]

36. Wang, F.; Yang, L.; Sun, G.; Guan, L.; Hu, S. The hierarchical porous structure of substrate enhanced photocatalytic activity of $\mathrm{TiO}_{2}$ /cementitious materials. Constr. Build. Mater. 2014, 64, 488-495. [CrossRef]

37. Husken, G.; Hunger, M.; Brouwers, H. Experimental study of photocatalytic concrete products for air purification. Build. Environ. 2009, 44, 2463-2474. [CrossRef]

38. Folli, A.; Pade, C.; Hansen, T.B.; De Marco, T.; Macphee, D.E. TiO 2 photocatalysis in cementitious systems: Insights into self-cleaning and depollution chemistry. Cem. Concr. Res. 2012, 42, 539-548. [CrossRef]

39. Wang, J.; Lu, C.; Xiong, J. Self-cleaning and depollution of fiber reinforced cement materials modified by neutral $\mathrm{TiO}_{2} / \mathrm{SiO}_{2}$ hydrosol photoactive coatings. Appl. Surf. Sci. 2014, 298, 19-25. [CrossRef]

40. Diamanti, M.V.; Paolini, R.; Rossini, M.; Aslan, A.B.; Zinzi, M.; Poli, T.; Pedeferri, M. Long term self-cleaning and photocatalytic performance of anatase added mortars exposed to the urban environment. Constr. Build. Mater. 2015, 96, 270-278. [CrossRef]

41. Rao, S.; da Silva, P.R.; de Brito, J. Experimental study of the mechanical properties and durability of self-compacting mortars with nano materials $\left(\mathrm{SiO}_{2}\right.$ and $\left.\mathrm{TiO}_{2}\right)$. Constr. Build. Mater. 2015, 96, 508-517. [CrossRef]

42. Liu, J.; Jin, H.; Gu, C.; Yang, Y. Effects of zinc oxide nanoparticles on early-age hydration and the mechanical properties of cement paste. Constr. Build. Mater. 2019, 217, 352-362. [CrossRef]

43. Duan, P.; Yan, C.; Luo, W.; Zhou, W. Effects of adding nano- $\mathrm{TiO}_{2}$ on compressive strength, drying shrinkage, carbonation and microstructure of fluidized bed fly ash based geopolymer paste. Constr. Build. Mater. 2016, 106, 115-125. [CrossRef]

44. Shen, W.; Zhang, C.; Li, Q.; Zhang, W.; Cao, L.; Ye, J. Preparation of titanium dioxide nano particle modified photocatalytic self-cleaning concrete. J. Clean. Prod. 2015, 87, 762-765. [CrossRef]

45. Khataee, R.; Heydari, V.; Moradkhannejhad, L.; Safarpour, M.; Joo, S.W. Self-Cleaning and Mechanical Properties of Modified White Cement with Nanostructured $\mathrm{TiO}_{2}$. J. Nanosci. Nanotechnol. 2013, 13, 5109-5114. [CrossRef]

46. de Melo, J.V.S.; Triches, G. Study of the influence of nano- $\mathrm{TiO}_{2}$ on the properties of Portland cement concrete for application on road surfaces. Road Mater. Pavement Des. 2018, 19, 1011-1026. [CrossRef]

47. Chen, D.; Ai, S.; Liang, Z.; Wei, F. Preparation and photocatalytic properties of zinc oxide nanoparticles by microwave-assisted ball milling. Ceram. Int. 2016, 42, 3692-3696. [CrossRef]

48. Mendoza, C.; Valle, A.; Castellote, M.; Bahamonde, A.; Faraldos, M. TiO 2 and $\mathrm{TiO}_{2}-\mathrm{SiO}_{2}$ coated cement: Comparison of mechanic and photocatalytic properties. Appl. Catal. B Environ. 2014, 178, 155-164. [CrossRef]

49. Guo, M.-Z.; Maury-Ramirez, A.; Poon, C.S. Self-cleaning ability of titanium dioxide clear paint coated architectural mortar and its potential in field application. J. Clean. Prod. 2016, 112, 3583-3588. [CrossRef]

50. Arefi, M.R.; Rezaei-Zarchi, S. Synthesis of Zinc Oxide Nanoparticles and Their Effect on the Compressive Strength and Setting Time of Self-Compacted Concrete Paste as Cementitious Composites. Int. J. Mol. Sci. 2012, 13, 4340-4350. [CrossRef] 
51. Sobolev, K.; Sanchez, F.; Flores, I. The Use of Nanoparticle Admixtures to Improve the Performance of Concrete. In Proceedings of the 4th International FIB Congress, Mumbai, India, 10-14 February 2014; Volume 10, pp. 1-8.

52. Yousefi, A.; Allahverdi, A.; Hejazi, P. Effective dispersion of nano- $\mathrm{TiO}_{2}$ powder for enhancement of photocatalytic properties in cement mixes. Constr. Build. Mater. 2013, 41, 224-230. [CrossRef]

53. Ma, B.; Li, H.; Li, X.; Mei, J.; Lv, Y. Influence of nano-TiO 2 on physical and hydration characteristics of fly ash-cement systems. Constr. Build. Mater. 2016, 122, 242-253. [CrossRef]

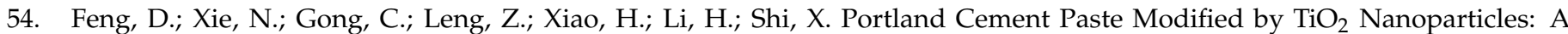
Microstructure Perspective. Ind. Eng. Chem. Res. 2013, 52, 11575-11582. [CrossRef]

55. Nivethitha, D.; Dharmar, S. Influence of Zinc Oxide Nanoparticle on Strength and Durability of Cement Mortar. Int. J. Earth Sci. Eng. 2016, 9, 175-181.

56. Aissa, A.H.; Puzenat, E.; Plassais, A.; Herrmann, J.-M.; Haehnel, C.; Guillard, C. Characterization and photocatalytic performance in air of cementitious materials containing $\mathrm{TiO}_{2}$. Case study of formaldehyde removal. Appl. Catal. B Environ. 2011, 107, 1-8. [CrossRef]

57. Yang, L.; Wang, F.; Du, D.; Liu, P.; Zhang, W.; Hu, S. Enhanced photocatalytic efficiency and long-term performance of TiO 2 in cementitious materials by activated zeolite fly ash bead carrier. Constr. Build. Mater. 2016, 126, 886-893. [CrossRef]

58. Li, Z.; Ding, S.; Yu, X.; Han, B.; Ou, J. Multifunctional cementitious composites modified with nano titanium dioxide: A review. Compos. Part A Appl. Sci. Manuf. 2018, 111, 115-137. [CrossRef]

59. Marco, D.; Fava, T.; Fava, G.; Guerrini, G.L.; Manganelli, G.; Moriconi, G.; Riderelli, L. Use of photocatalytic products for sustainable construction development. In Proceedings of the Third International Conferences on Sustainable Construction Materials and Technologies, Kyoto, Japan, 18-21 August 2013; pp. 1-7.

60. Jayapalan, A.R.; Lee, B.Y.; Kurtis, K.E. Can nanotechnology be 'green'? Comparing efficacy of nano and microparticles in cementitious materials. Cem. Concr. Compos. 2013, 36, 16-24. [CrossRef]

61. Boostani, H.; Modirrousta, S. Review of Nanocoatings for Building Application. Procedia Eng. 2016, 145, 1541-1548. [CrossRef]

62. Stefanidou, M.; Papayianni, I. Influence of nano-SiO 2 on the Portland cement pastes. Compos. Part B Eng. 2012, 43, 2706-2710. [CrossRef]

63. Senff, L.; Tobaldi, D.M.; Rachadel, P.L.; Labrincha, J.; Hotza, D. The influence of $\mathrm{TiO}_{2}$ and $\mathrm{ZnO}$ powder mixtures on photocatalytic activity and rheological behavior of cement pastes. Constr. Build. Mater. 2014, 65, 191-200. [CrossRef]

64. Nazari, A.; Riahi, S. The Effects of $\mathrm{ZnO}_{2}$ nanoparticles on strength assessments and water permeability of concrete in different curing media. Mater. Res. 2011, 14, 178-188. [CrossRef]

65. Liu, J.; Li, Q.; Xu, S. Influence of nanoparticles on fluidity and mechanical properties of cement mortar. Constr. Build. Mater. 2015, 101, 892-901. [CrossRef]

66. Ghafari, E.; Ghahari, S.; Feng, Y.; Severgnini, F.; Lu, N. Effect of Zinc oxide and Al-Zinc oxide nanoparticles on the rheological properties of cement paste. Compos. Part B Eng. 2016, 105, 160-166. [CrossRef]

67. Rhee, I.; Lee, J.-S.; Kim, J.B. Nitrogen Oxides Mitigation Efficiency of Cementitious Materials Incorporated with TiO 2. Materials 2018, 11, 877. [CrossRef] [PubMed]

68. Shen, S.; Burton, M.; Jobson, B.; Haselbach, L. Pervious concrete with titanium dioxide as a photocatalyst compound for a greener urban road environment. Constr. Build. Mater. 2012, 35, 874-883. [CrossRef]

69. Yang, L.; Gao, Y.; Wang, F.; Liu, P.; Hu, S. Enhanced photocatalytic performance of cementitious material with TiO ${ }_{2} @ A_{g}$ modified fly ash micro-aggregates. Chin. J. Catal. 2017, 38, 357-364. [CrossRef]

70. Duan, P.; Yan, C.; Zhou, W.; Ren, D. Fresh properties, compressive strength and microstructure of fly ash geopolymer paste blended with iron ore tailing under thermal cycle. Constr. Build. Mater. 2016, 118, 76-88. [CrossRef]

71. Meng, T.; Yu, Y.; Qian, X.; Zhan, S.; Qian, K. Effect of nano-TiO 2 on the mechanical properties of cement mortar. Constr. Build. Mater. 2012, 29, 241-245. [CrossRef]

72. Yang, L.Y.; Jia, Z.J.; Zhang, Y.M.; Dai, J.G. Effects of nano- $\mathrm{TiO}_{2}$ on strength, shrinkage and microstructure of alkali activated slag pastes. Cem. Concr. Compos. 2015, 57,1-7. [CrossRef]

73. Vu, T.V.; Nguyen, T.V.; Tabish, M.; Ibrahim, S.; Hoang, T.H.T.; Gupta, R.K.; Dang, T.M.L.; Nguyen, T.A.; Yasin, G. Water-Borne ZnO/Acrylic Nanocoating: Fabrication, Characterization, and Properties. Polymers 2021, 13, 717. [CrossRef] [PubMed]

74. Li, X.; Ma, X.; Zhang, S.; Zheng, E. Mechanical Properties and Microstructure of Class C Fly Ash-Based Geopolymer Paste and Mortar. Materials 2013, 6, 1485-1495. [CrossRef] [PubMed]

75. Farhana, Z.; Kamarudin, H.; Rahmat, A.; Al Bakri, A.M. The Relationship between Water Absorption and Porosity for Geopolymer Paste. Mater. Sci. Forum 2014, 803, 166-172. [CrossRef]

76. Nath, P.; Sarker, P.K.; Rangan, V.B. Early Age Properties of Low-calcium Fly Ash Geopolymer Concrete Suitable for Ambient Curing. Procedia Eng. 2015, 125, 601-607. [CrossRef]

77. Zhuang, X.; Chen, L.; Komarneni, S.; Zhou, C.H.; Tong, D.; Yang, H.; Yu, W.; Wang, H. Fly Ash-based Geopolymer: Clean Production, Properties and Applications. J. Clean. Prod. 2016, 125, 253-267. [CrossRef]

78. Assi, L.; Ghahari, S.; Deaver, E.; Leaphart, D.; Ziehl, P. Improvement of the early and final compressive strength of fly ash-based geopolymer concrete at ambient conditions. Constr. Build. Mater. 2016, 123, 806-813. [CrossRef]

79. Lee, B.; Kim, G.; Kim, R.; Cho, B.; Lee, S.; Chon, C.-M. Strength development properties of geopolymer paste and mortar with respect to amorphous $\mathrm{Si} / \mathrm{Al}$ ratio of fly ash. Constr. Build. Mater. 2017, 151, 512-519. [CrossRef] 
80. Sahana, R. Setting Time, Compressive Strength and Microstructure of Geopolymer Paste. Int. J. Innov. Res. Sci. Eng. Technol. 2013, 2, 311-316.

81. Duan, P.; Yan, C.; Zhou, W. Compressive strength and microstructure of fly ash based geopolymer blended with silica fume under thermal cycle. Cem. Concr. Compos. 2017, 78, 108-119. [CrossRef]

82. Li, H.; Gao, P.; Xu, F.; Sun, T.; Zhou, Y.; Zhu, J.; Peng, C.; Lin, J. Effect of Fine Aggregate Particle Characteristics on Mechanical Properties of Fly Ash-Based Geopolymer Mortar. Minerals 2021, 11, 897. [CrossRef]

83. Guerrero, L.E.; Gómez-Zamorano, L.; Jiménez-Relinque, E. Effect of the addition of $\mathrm{TiO}_{2}$ nanoparticles in alkali-activated materials. Constr. Build. Mater. 2020, 245, 118370. [CrossRef]

84. Syamsidar, D. The Properties of $\mathrm{Nano}_{\mathrm{TiO}}$-Geopolymer Composite as a Material for Functional Surface Application. MATEC Web Conf. 2017, 97, 1013. [CrossRef]

85. Sastry, K.G.K.; Sahitya, P.; Ravitheja, A. Influence of nano TiO2 on strength and durability properties of geopolymer concrete. Mater. Today Proc. 2020, 45, 1017-1025. [CrossRef] 